\title{
An Overview of Issues Affecting the Demand for Dry and Wet/Dry Cooling for Thermal Power Plants
}

\author{
P. L. Hendrickson
}

September 1978

Prepared for the U.S. Department of Energy under Contract EY-76-C-06-1830

Pacific Northwest Laboratory Operated for the U.S. Department of Energy by 
NOTICE

This report was prepared as an account of work sponsored by the United States Government. Neither the United States nor the Department of Energy, nor any of their employees, nor any of their contractors, subcontractors, or their employees, makes any warranty, express or implied, or assumes any legal liability or responsibility for the accuracy, completeness or usefuiness of any information, apparatus, product or process disclosed, or represents that its use would not infringe privately owned rights.

The views, opinions and conclusions contained in this report are those of the contractor and do not necessarily represent those of the United Siates Government or the United States Department of Energy.

\author{
PACIFIC NORTHWEST LABORATORY \\ operated by \\ BATTELLE \\ for the \\ UNITED STATES DEPARTMENT OF ENERGY \\ Under Contract EY-76-C-06-1830
}

Printed in the United States of America

Available from

National Technical Intormation Service

United States Department of Commerce

5285 Port Royal Road

Springfield, Virginia 22151

Price: Printed Copys

$\therefore$ Microfiche $\$ 3.00$

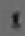

NTIS

-Pages Selling Price

$\begin{array}{lr}001-025 & \$ 4.00 \\ 026-050 & \$ 4.50 \\ 051-075 & \$ 5.25 \\ 076-100 & \$ 6.00 \\ 101-125 & \$ 6.50 \\ 126-150 & 57.25 \\ 151-175 & \$ 8.00 \\ 176-200 & 59.00 \\ 201-225 & 59.25 \\ 226-250 & 59.50 \\ 251-275 & \$ 10.75 \\ 276-300 & \$ 11.00\end{array}$


AN OVERVIEW OF ISSUES AFFECTING THE DEMAND FOR DRY AND WET/DRY COOL ING FOR THERMAL POWER PLANTS

P. L. Hendrickson

September 1978

Prepared for the U.S. Department of Energy under Contract EY-76-C-06-1830

Pacific Northwest Laboratory Richland, Washington 99352 
FOREWORD

The Dry Cooling Enhancement Program at the Pacific Northwest Laboratory (PNL) was initiated with a program scope that included the following near-term and ultimate emphases.

Near-Term Objectives:

- Develop economic and performance models for cost optimization of total heat rejection systems using dry and dry/wet cooling.

- Analyze and disseminate operating experience on existing drycooled plant performance.

- Demonstrate certain features of existing technology equipment to provide confidence for specification by utilities.

Ultimate Objective:

- Promote water conservation through industry use of dry cooling by developing and demonstrating the reliability of lowercost systems. The development of advanced dry/wet systems is also considered to be within this scope.

The following documents have been issued, reporting the results of the work toward these objectives.

Cost optimization of dry-cooled heat rejection systems:

A REVIEW AND ASSESSMENT OF ENGINEERING ECONOMIC STUDIES OF DRY COOLED ELECTRICAL GENERATINIG PLANTS. B. C. Fryer, BNWL-1976, March 1976.

HEAT TRANSFER AND PRESSURE DROP CHARACTERISTICS OF DRY TOWER EXTENDED SURFACES. PART I: HEAT TRANSFER AND PRESSURE DROP DATA. PFR Engineering Systems, Inc., PFR 7-100, March 1976.

HEAT TRANSFER AND PRESSURE DROP CHARACTERISTICS OF DRY TOWER EXTENDED SURFACES. PART II : DATA ANALYSIS AND CORRELATION. PFR Engineering Systems, Inc., PFR 7-102, June 1976. 
Analys is of performance of existing dry-cooled plants:

DRY COOLING TOWER PROGRAM: RESULTS OF INDUSTRIAL CONTACTS

THROUGH AUGUST 1974. BNWL-1878, November 1, 1974.

A SURVEY OF MATERIALS AND CORROSION PERFORMANCE IN DRY COOLING APPLICATIONS. A. B. Johnson, Jr., D. R. Pratt and G. E. Zima, BNWL-1958, March 1976.

EUROPEAN DRY COOLING TOWER OPERATING EXPERIENCE.

J. G. DeSteese and K. Simhan, BNWL-1995, March 1976.

MATHEMATICAL AND EXPERIMENTAL INVESTIGATIONS ON DISPERSION AND RECIRCULATION OF PLUMES FROM DRY COOLING TOWERS

AT WYODAK POWER PLANT IN WYOMING. Y. Onishi and

D. S. Trent, BNWL-1982, February 1976.

ALUMINUM ALLOY PERFORMANCE UNDER DRY COOLING TOWER CONDITIONS. A. B. Johnson, Jr., S. Begaj, M. W. Martini, and R. P. May, PNL-2392, December 1977.

Advanced dry (dry/wet) cooled systems:

PRELIMINARY EVALUATION OF WET/DRY COOLING CONCEPTS FOR

POWER PLANTS. W. V. LOSCutoff, BNWL-1969.

COMPATABILITY OF AMMONIA WITH CANDIDATE DRY COOLING SYSTEM

MATERIALS. D. R. Pratt, BNWL-1992, Apri1 1976.

SCALE FORMATION IN DELUGED DRY COOLING SYSTEMS. D. R. Pratt, BNWL-2060, March 1976.

AMMONIA AS AN INTERMEDIATE HEAT EXCHANGE FLUID FOR DRY

COOLED TOWERS. R. T. ATlemann, B. M. Johnson, and

G. C. Smith, BNWL-SA-5997, September 1976.

Another group of reports serves the dual purpose of developing cost optimization models for dry cooling systems based on available technology and comparing the results of analyzing the costs of these systems with the projected cost of several advanced dry and dry/wet systems. Included in this group are:

AN ENGINEERING AND COST COMPARISON OF THREE DIFFERENT

ALL-DRY COOLING SYSTEMS. B. C. Fryer, D. W. Faletti,

Daniel J. Braun, David J. Braun and L. E. Wiles, BNWL-2121, September 1976. 
A STUDY OF THE COMPARATIVE COSTS OF FIVE WET/DRY COOLING TOWER CONCEPTS. F. R. Zaloudek, R. T. Allemann, D. W. Faletti, B. M. Johnson, H. L. Parry, G. C. Smith, R. D. Tokarz, and R. A. Walter, BNWL-2122, September 1976.

DRY COOLING OF POWER GENERATING STATIONS: A SUMMARY OF THE ECONOMIC EVALUATION OF SEVERAL ADVANCED CONCEPTS VIA A DESIGN OPTIMIZATION STUDY AND A CONCEPTUAL DESIGN AND COST ESTIMATE. B. M. Johnson, R. T. Allemann, D. W. Faletti, B. C. Fryer and F. R. Zaloudek, BNWL-2120, September 1976.

COSTS AND COST ALGORITHMS FOR DRY COOLING TOWER SYSTEMS. P. A. Ard, C. H. Henager, D. R. Pratt and L. E. Wiles, BNWL-2123, September 1976.

A USER'S MANUAL FOR THE BNW-I OPTIMIZATION CODE FOR DRYCOOLED POWER PLANTS. David J. Braun, Daniel J. Braun, Warren V. De Mier, D. W. Faletti and L. E. Wiles, BNWL-2180, January 1977.

COMPARATIVE COST STUDY OF FOUR WET/DRY COOLING CONCEPTS THAT USE AMMONIA AS THE INTERMEDIATE HEAT EXCHANGE FLUID R. D. Tokarz, Daniel J. Braun, B. M. Johnson, R. T. Allemann, David J. Braun, H. L. Parry, G. C. Smith and F. R. Zaloudek, PNL-2661, May 1978.

A DESCRIPTION AND COST ANALYSIS OF A DELUGE DRY/WET COOLING SYSTEM. L. E. Wiles, J. A. Bamberger, Daniel J. Braun, David J. Braun, D. W. Faletti and C. E. Willingham, PNL-2498, June 1978.

A USER'S MANUAL FOR THE BNW-II OPTIMIZATION CODE FOR DRY/WETCOOLED POWER PLANTS. DanieT J. Braun, Judith A. Bamberger, David J. Braun, Duane W. Faletti and Larry E. Wiles, PNL-2674, May 1978.

Two reports have been issued which consider the future need for wet/dry cooling and the potential benefit/cost ratio of a large-scale demonstration.

AN OVERVIEW OF ECONOMIC, LEGAL, AND WATER AVAILABILITY FACTORS AFFECTING THE DEMAND FOR DRY AND WET/DRY COOLING OF THERMAL POWER PLANTSS. P. L. Hendrickson, BNWL-2268, June 1977.

ESTIMATION OF BENEFITS FROM DEMONSTRATING ADVANCED DRY COOLING TECHNOLOGY: A FRAMEWORK AND PART IAL ANALYSIS. J. W. Currie and T. J. Foley, BNWL-2182, Apri1 1977. 
This report considers the economic, legal, and water availability factors that will contribute to future selection of dry and wet/dry cooling and thus influence the projected market for these types of cooling systems in the next 20 years. This report is a revised and updated version of BNWL-2268, originally issued in June 1977. 
It appears likely that on the order of 20 GWe of thermal power plant capacity will utilize wet/dry cooling through the year 2000 . The requirement could conceivably be as low as 10 GWe or as high as 45 GWe. The amount of totally dry cooling needed is estimated to be small because of its extraordinary high cost relative to other cooling alternatives. The area with the greatest likelihood for utilizing wet/dry cooling is the Southwest, from California to Texas. This area has the greatest physical shortage of water in the country and thus will likely experience the greatest water allocation pressures.

Where water is available, the optimal economic decision will be to utilize wet cooling. The breakeven point where wet/dry cooling would be selected over totally wet cooling is at a water cost in the range of about $\$ 1.80$ to $\$ 2.70 / 1000$ gal (1977 dollars) depending on geographic location. Various water sources are available which can provide water at less than this cost, including conveyance and treatment of agricultural and municipal waste water (about $\$ 0.60$ to $\$ 0.80 / 1000$ gal) and outright purchase of irrigated farms to acquire water rights (about $\$ 0.25 / 1000 \mathrm{gal}$ ). Further research on the extent to which these sources are available for cooling seems warranted.

Although cooling economics favor wet cooling, wet/dry cooling will still be used in certain circumstances for several reasons. In the near term, its principal advantage will be to provide plant location flexibility. A few mine-mouth coal-fired plants will likely utilize dry or wet/dry cooling when transporting the coal to an area with water is more expensive than wet/dry cooling. The Wyodak facility in Wyoming and San Juan III in northwestern New Mexico are examples. Wet/dry cooling may be selected (if adequate water is unavailable for wet cooling) in order to locate a power plant at a site already occupied by another plant(s). The utility would thus be able to take advantage of existing transmission corridors, avoid creating another boom town, and take advantage of certain economies-ofscale. The San Juan III facility is also an example of this case. Wet/dry cooling could be selected in order to locate a power plant near a load center 
and thereby reduce transmission line losses. Actual physical shortage of water and storage capacity will lead to a limited amount of wet/dry cooling in the Southwest. Finally, political considerations will lead to some wet/dry cooling. Most likely these will take the form of restrictions on the transfer of water from agricultural to industrial use.

When free transfer of water rights is permitted, the vast quantity of water used for irrigation (over $80 \%$ of total water consumption in nearly all of the western states) and the fact that water is worth at least five times as much to a utility as to a farmer, will combine to limit the use of wet/dry cooling.

If the transfer of water rights to new uses is restricted, wet/dry cooling will be more common. There is some indication that restrictions on water use and transfer are increasing. The California State Water Resources Control Board currently has a policy of not approving the use of inland water for power plant cooling unless the water is sufficiently saline to have little or no agricultural value. Montana amended its water code in 1975 to prohibit transfer of water rights greater than 15 cfs from agricultural to industrial use. North Dakota enacted legislation in 1977 which effectively prohibits any water transfer from agricultural to industrial use. Three western states--0k1ahoma, Nevada, and South Dakota--appear to prohibit the transfer of water to a new location. Many of these restrictions seem to reflect concerns that established agricultural and community infrastructure will be damaged by water transfers. If these types of policies expand to other states, especially those in the Southwest, more than 20 GWe of wet/dry cooling will likely be needed by the year 2000 . 
FOREWORD

SUMMARY

LIST OF TABLES .

LIST OF FIGURES

1.0 INTRODUCTION

2.0 COOLING ALTERNATIVES

2.1 ONCE-THROUGH COOLING $\quad$.

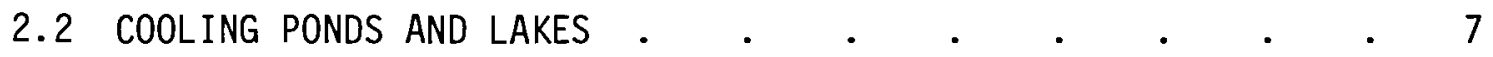

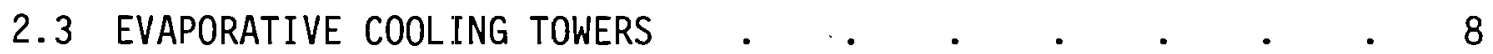

2.4 DRY AND WET/DRY COOLING .

3.0 ECONOMICS OF COOLING TOWER ALTERNATIVES •

3.1 RELATIVE COST OF ALTERNATIVES • . . . . . . . . 11

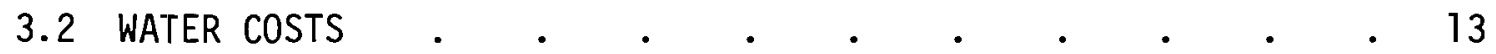

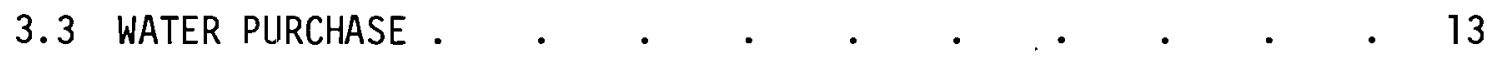

3.3.1 Water Treatment and Delivery . . . . . . 14

3.3.2 Municipal Waste Water . . . . . . . 15

3.3.3 Agricultural Waste Water . . . . . . 16

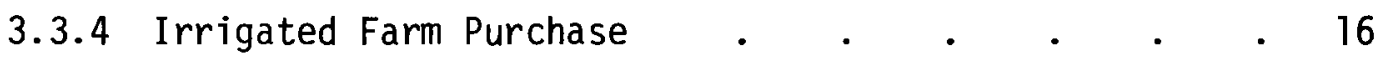

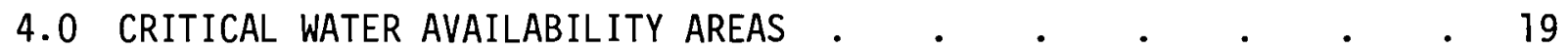

4.1 WATER AVAILABILITY AND CONSUMPTION IN THE U.S. • • • 19

4.2 REVIEW OF STUDIES ESTIMATING THE DEMAND FOR WET/DRY COOLING . 20

4.3 REGIONAL PROJECTIONS OF WATER AVAILABILITY FOR COOLING . • 22

4.3.1 Colorado River Basin . . . . . . . . 22

4.3.2 Rio Grande River Basin. . . . . . . . . 24 
4.3.3 Upper Missouri River Basin . . . . . . . 25

4.3.4 California . . . . . . . . . . . . . 26

5.0 ALTERNATIVES FOR ACQUIRING INLAND WATER AND ASSOCIATED

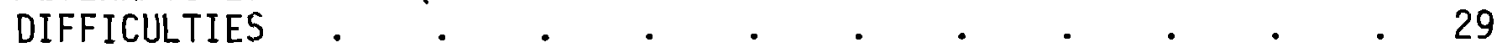

5.1 APPROPRIATION .

5.2 EXERCISE OF RIPARIAN RIGHTS . . . . . . . . . . . 30

5.3 ACQUISITION FROM FEDERAL WATER PROJECTS . . . . . . . 31

5.4 TRANSFER OF STATE WATER RIGHTS . . . . . . . . 33

5.4.1 Appropriation System . . . . . . . 34

5.4 .2 Riparian System . . . . . . . . . 38

5.4.3 Water Management Organizations . . . . . 38

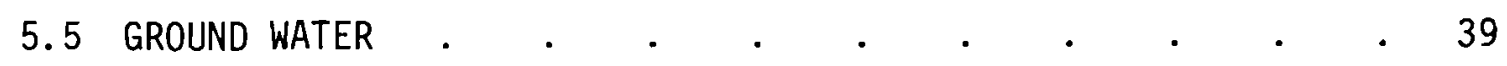

6.0 LEGAL UNCERTAINTIES COMPLICATING THE ACQUISITION OF WATER . $\quad 43$

6.1 INDIAN WATER RIGHTS .

6.2 OTHER FEDERAL RESERVED RIGHTS . . . . . . . . . . 44

6.3 PRESERVATION OF INSTREAM WATER . . . . . . . . 45

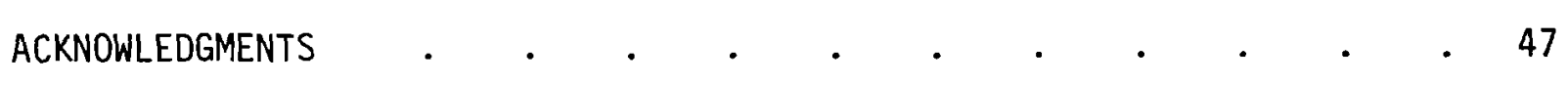

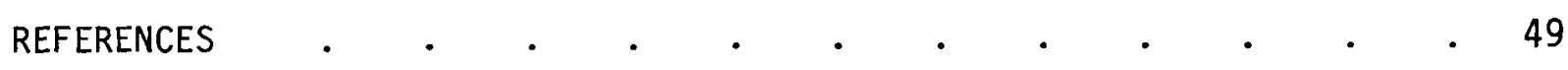




\section{$\underline{\text { TABLES }}$}

1. Steam-Electric Generating Forecasts (GWe) . . . . . 2

2. 1970 Mix in Percent (by Capacity) of Cooling System Type . . 3

3. Typical Water Consumption Data for Alternative Cooling Modes . 4

4. Cooling System Costs . . . . . . . . . . 5

5. Water Breakeven Costs . . . . . . . . . . . 11

6. Water Treatment and Supply Costs for Six Power Plant Sites . . 14

7. Cost of Water Acquired by Purchasing Irrigated Farms . . . 17

8. Components of the National Wild and Scenic Rivers System . . 46

\section{FIGURES}

1. Upper Colorado River Basin Water for Energy, 1974 to 2000 . 23 
AN OVERVIEW OF ECONOMIC, LEGAL, AND WATER AVAILABILITY FACTORS AFFECTING

THE DEMAND FOR DRY AND WET/DRY COOLING FOR THERMAL POWER PLANTS

\subsection{INTRODUCTION}

The purpose of the study is to identify and discuss some of the important factors which will affect the demand for dry and wet/dry cooling of thermal power plants during the remainder of this century. The paper begins by discussing cooling alternatives and their advantages, disadvantages, and relative costs. Critical water supply geographic areas are identified. Finally, alternatives for acquiring water for cooling and associated legal difficulties are discussed.

Consumption of electricity in the United States continues to increase. A11 forecasts point to further increases through this century, although the forecasts make varying growth rate assumptions. Two growth forecasts for fossil and nuclear generating capacity are shown in Table 1. A new forecast by water resource region will soon be published in Part III of The Second National Water Assessment being prepared by the U.S. Water Resources Council.

The Utility Water Act Group (UWAG), composed of certain members of the Edison Electric Institute, estimates in Table 1 are based on $7 \%$ annual growth in electric capacity. The Energy Research and Development Administration (ERDA) estimates assume $5 \%$ annual growth.

Virtually all existing thermal power plants require air or water as a heat sink to which waste heat can be expelled. There is a strong potential for using some of the waste heat beneficially for district heating, greenhouses, and certain industrial process applications. However, it appears likely that the major advantage of these uses will be energy conservation and perhaps to reduce costs in the alternative applications. (4) It is not likely that cooling tower hardware can be eliminated for at least two reasons. First, it is very unlikely that all of a plant's waste heat can be beneficially used; second, full cooling hardware will likely be required as a back-up to reject heat use. 


\section{TABLE 1. Steam-Electric Generating Forecasts (GWe)}

Water Resource Region

1. New England

2. Mid-Atlantic

3. South Atlantic

4. Great Lakes

5. Ohio

6. Tennessee

7. Upper Mississippi

8. Lower Mississippi

9. Souris-Red-Rainy

10. Missouri Basin

11. Arkansas-White-Red

12. Texas-Gulf

13. Rio Grande

14. Upper Colorado

15. Lower Colorado

16. Great Basin

17. Pacific Northwest

18. California

Total Contiguous U.S.

\begin{tabular}{|c|c|c|c|c|c|c|c|c|c|}
\hline \multicolumn{2}{|c|}{$1970^{3}$} & \multicolumn{2}{|c|}{1983 (UWAG) } & \multicolumn{2}{|c|}{1983 (ERDA) $^{2}$} & \multicolumn{2}{|c|}{2000 (UWAG) $^{3}$} & \multicolumn{2}{|c|}{2000 (ERDA) ${ }^{2}$} \\
\hline Fossil & Nuclear & Fossill & Nuclear & Fossil & Nuclear & Fossll & Nuclear & Fossill & Nucla \\
\hline 10.6 & 1.4 & 19.4 & 18.7 & 13.9 & 11.4 & 22.6 & 90.5 & 31.6 & 20.5 \\
\hline 35.1 & 0.61 & 60.4 & 13.1 & 33.2 & 27.4 & 73.2 & 170.9 & 68.1 & 44.1 \\
\hline 31.4 & - & 77.3 & 38.8 & 42.1 & 34.7 & 137.8 & 413.4 & 153.7 & 99.6 \\
\hline 25.5 & 1.6 & 62.7 & 13.8 & 27.8 & 22.9 & 78.7 & 118.1 & 54.9 & 35.5 \\
\hline 43.9 & 0.10 & 101.6 & 22.3 & 45.0 & 37.0 & 127.6 & 191.3 & 88.9 & 57.6 \\
\hline 9.4 & - & 14.3 & 12.0 & 9.5 & 7.9 & 11.7 & 46.9 & 16.4 & 10.6 \\
\hline 18.4 & 1.0 & 31.2 & 17.4 & 17.6 & 14.5 & 55.3 & 102.6 & 44.0 & 28.5 \\
\hline 10.5 & - & 27.9 & 5.7 & 12.2 & 10.0 & 57.5 & 86.2 & 40.0 & 26.0 \\
\hline 0.25 & - & 0.56 & 0.24 & 0.29 & 0.24 & 0.70 & 1.6 & 0.66 & 0.42 \\
\hline 8.7 & - & 19.4 & 8.1 & 10.0 & 8.2 & 24.2 & 56.5 & 22.5 & 14.6 \\
\hline 10.8 & - & 28.5 & 5.8 & 12.5 & 10.3 & 58.7 & 88.0 & 40.9 & 26.5 \\
\hline 20.6 & - & 53.5 & 9.9 & 23.0 & 19.0 & 81.9 & 122.8 & 57.1 & 37.0 \\
\hline 1.9 & - & 6.5 & - & 2.4 & - & 20.3 & - & 5.6 & - \\
\hline 2.7 & - & 5.8 & 0.21 & 2.2 & 1.8 & 11.4 & 4.9 & 4.5 & 2.9 \\
\hline 2.5 & - & 8.9 & 1.4 & 3.8 & 3.1 & 22.5 & 22.5 & 12.5 & 8.1 \\
\hline 0.96 & - & 0.96 & - & 0.35 & - & 0.96 & - & 0.27 & - \\
\hline 0.13 & 1.0 & 3.9 & 2.7 & 2.4 & 2.0 & 10.6 & 31.8 & 11.8 & 7.6 \\
\hline 19.2 & 0.53 & 32.5 & 8.2 & 14.8 & 12.2 & 49.3 & 91.6 & 39.3 & 25.5 \\
\hline 252.9 & 6.3 & 555.7 & 196.5 & 273.0 & 225.0 & 845.0 & $1,639.8$ & 693.0 & 449.0 \\
\hline
\end{tabular}

${ }^{2}$ ERDA-48, Scenario V (June 1975), U.S. Forecast Divided into Water Resource Regions by Reference 3 ratios.

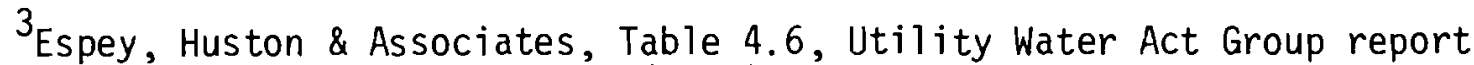
Section IX, from FPC Form 67 (1973).

SOURCE: Ref. 1. 


\subsection{COOL ING ALTERNATIVES}

There are five principal options available to provide cooling for thermal power plants: once-through cooling, cooling ponds and lakes, closed cycle evaporative cooling towers, wet/dry cooling towers, and dry cooling towers. The 1970 relative mix of each type of cooling is shown in Table 2. Dry and wet/dry cooling are essentially zero percent.

TABLE 2. 1970 Mix in Percent (by Capacity) of Cooling System Type

\begin{tabular}{|c|c|c|c|c|}
\hline Water Resource Region & $\begin{array}{c}\text { Once- } \\
\text { Through } \\
\text { Saline } \\
\end{array}$ & $\begin{array}{l}\text { Once- } \\
\text { Through } \\
\text { Fresh } \\
\end{array}$ & $\begin{array}{l}\text { Cooling } \\
\text { Pond } \\
\end{array}$ & $\begin{array}{l}\text { Cooling } \\
\text { Tower } \\
\end{array}$ \\
\hline 1. New England & 71.51 & 28.49 & --- & --- \\
\hline 2. Middle Atlantic & 61.09 & 38.91 & --- & --- \\
\hline 3. South Atlantic - Gulf & 37.38 & 55.33 & 4.57 & 2.72 \\
\hline 4. Great Lakes & --- & 99.70 & 0.16 & 0.14 \\
\hline 5. Ohio & --- & 83.57 & $z^{-1}$ & 16.43 \\
\hline 6. Tennessee & --- & 90.73 & 2.19 & 7.08 \\
\hline 7. Upper Mississippi & 12.44 & 85.08 & 13.46 & 1.46 \\
\hline 8. Lower Mississippi & --- & 68.53 & -- & 19.03 \\
\hline 9. Souris - Red - Rainy & -- & 100.00 & -- & -- \\
\hline 10. Missouri Basin & -- & 58.12 & 19.44 & 22.44 \\
\hline 11. Arkansas - White - Red & --- & 13.20 & 21.77 & 65.03 \\
\hline 12. Texas - Gulf & 27.30 & 15.30 & 36.00 & 21.40 \\
\hline 13. Rio Grande & --- & -.- & --- & 100.00 \\
\hline 14. Upper Colorado & -- & -- & 86.58 & 13.42 \\
\hline 15. Lower Colorado & --- & --- & 4.87 & 95.13 \\
\hline 16. Great Basin & -- & 10.17 & 13.32 & 76.51 \\
\hline 17. Pacific Northwest & 5.14 & 94.86 & -- & --- \\
\hline 18. California & 78.27 & 6.48 & --- & 15.25 \\
\hline
\end{tabular}

SOURCE: Ref. 5.

The relative water consumption of each cooling mechanism is shown in Table 3. The values in Table 3 are approximately consistent for a single site, but would change somewhat for different sites. The water 
TABLE 3. Typical Water Consumption Data for Alternative Cooling Modes

\begin{tabular}{|c|c|}
\hline & $\begin{array}{l}\text { Approximate Annual } \\
\text { Gallons/Hour Per Gross kWe }\end{array}$ \\
\hline Cooling Mode & Fossil* $\quad$ Nuclear (LWR)† \\
\hline
\end{tabular}

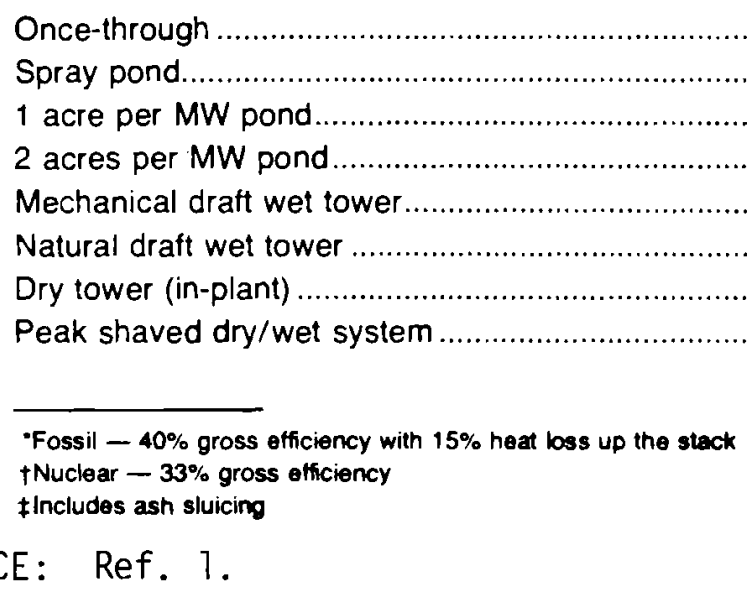

.0 .30

0.45

0.40

0.60

0.75

1.0

0.65

0.57

0.015

$0.022 \ddagger$

$0.02-0.07$

SOURCE: Ref. 1 .

consumption shown in Table 3 plus blowdown liquid discharge is the total water withdrawal requirement for a plant. More detailed information on cooling tower and pond water consumption is available in Reference 6 . The approximate relative cost of alternative cooling systems in selected locations is shown in Table 4. The total evaluated cost is the sum of the capital costs, annualized operating costs, and penalty costs associated with reductions below the plant's firm power rating. The cost of the water is not included.

The use of once-through cooling and cooling lakes was previously limited by regulations of the U.S. Environmental Protection Agency (EPA). These regulations were set aside in a court case in July 1976. It is possible that limited use of these cooling modes may be acceptable in the future.

\subsection{ONCE-THROUGH COOLING}

Historically, once-through cooling without cooling towers has been the most common form of thermal power plant cooling, principally because of its low cost. This form of cooling was criticized for the ecological impact of the waste heat discharge. The Federal Water Pollution Control Act Amendments of 1972 (FWPCA) declared a national goal of eliminating the discharge of pollutants into navigable waters by $1985 .{ }^{(7)}$ Heat is included 
TABLE 4. Cooling System Costs (1978\$)

\begin{tabular}{|c|c|c|c|}
\hline \multirow[b]{2}{*}{ Cooling System } & \multirow[b]{2}{*}{ Location } & \multicolumn{2}{|c|}{ Total Evaluated Cost $(\$ / \mathrm{kW})$} \\
\hline & & Fossil Plant & Light Water Reactor \\
\hline Once-Through & Boston & 19.71 & 26.28 \\
\hline \multirow[t]{2}{*}{ Mechanical Wet } & Boston & 43.07 & 49.28 \\
\hline & Denver & 38.33 & 44.90 \\
\hline \multirow[t]{2}{*}{ Natural Wet } & Boston & 47.09 & 50.37 \\
\hline & Denver & 41.61 & 45.99 \\
\hline \multirow{2}{*}{$\begin{array}{l}\text { Fan Assisted } \\
\text { Natural Wet }\end{array}$} & Boston & 45.63 & 51.47 \\
\hline & Denver & 41.61 & 47.09 \\
\hline Cooling Pond & Boston & 62.05 & 72.64 \\
\hline Spray Canal & Boston & 44.17 & 51.10 \\
\hline $40 \%$ Wet/Dry & San Juan, N.M. & 80.67 & 97.46 \\
\hline $10 \%$ wet/Dry & San Juan, N.M. & 104.39 & 129.21 \\
\hline $\begin{array}{l}\text { Mechanical Dry } \\
\text { with High Back } \\
\text { Pressure Turbine }\end{array}$ & San Juan, N.M. & 148.56 & 180.31 \\
\hline SOURCE: Ref.6. & & & \\
\hline
\end{tabular}

within the definition of pollutants. (8) The Act also provides (9) though, that the EPA Administrator can accept some thermal discharge if the protection and propagation of a balanced indigenous population of shellfish, fish, and wildlife in and on the receiving body of water is assured. EPA responded to FWPCA by promulgating regulations which provided that subject to limited exceptions:

1. All existing generating plants of 500 MWe or more which came on line after January 1, 1970, and al1 existing units regardless of size which begin operation after January 1, 1974, must backfit closed-cycle cooling systems by Ju1y 1, 1981. (10)

2. Discharge of heat from new steam electric power plants is permitted only in blowdown from recirculated cooling water systems and in blowdown from cooling ponds. (11) 
Thus, new generating units could not use cooling lakes. Cooling ponds are not restricted. (Cooling ponds and lakes are distinguished on page 7.)

Both of these requirements were set aside in Appalachian Power $v$. Train $^{(12)}$ in a suit brought by 70 utilities composing UWAG. Revised regulations have not yet been published. The status of once-through cooling for both existing and future plants is thus uncertain. In practice, the trend to closed-cycle cooling, especially for inland power plants, is unlikely to be reversed and once-through cooling may not be accepted on future plants. (a) If it is accepted in some areas, however, significant cost and water savings can be achieved.

The backfit requirements were set aside because the court found that EPA did not state the expected enivronmental benefits of reducing thermal pollution. The court left open the possibility that the regulations might be found acceptable if EPA can fully explicate the reasons for the regulations. In particular, the court requested that EPA state the incremental benefits (not necessarily in monetary terms) to be expected from incremental reductions in thermal discharges.

The second requirement, that new plants discharge heat only in blowdown from closed cycle cooling systems and cooling ponds, was also set aside. The principal reason stated for the court's decision was EPA's failure to consider the impact of regulations on water consumption in water-short areas. The court's decision to set aside these regulations raises the possibility that even once-through cooling may be accepted in limited areas for new thermal power plants.

Appalachian Power decided two other significant issues. First, it directed EPA to adopt a meaningful variance clause which would exempt

(a) The following quotation from a 1977 report, Implications of Environmental Regulations for Energy Production and Consumption, by a Committee of the National Research Council for EPA is, however, interesting:

We conclude that closed-cycle cooling is not currently cost-effective in most instances, either in energy or dollars. We recommend, therefore, that closed-cycle cooling not be required now when the effects of thermal pollution on ambient conditions, fish and wildlife are still negligible, but only when and where it is necessary to prevent significant harm to the environment. 
power plants from the thermal backfit requirement in certain circumstances. The decision also directed EPA to consider a request made by the Atomic Energy Commission (AEC) (now the Nuclear Regulatory Commission(NRC)) that 55 nuclear power plants that have completed environmental impact statements be exempt from backfit requirements.

One provision in the FWPCA which affects thermal power plant cooling merits mention. Section $306(c)$ of the Act permits states to apply and enforce standards stricter than EPA regulations if prior EPA approval for the state's permit system is obtained.

\subsection{COOLING PONDS AND LAKES}

The use of cooling lakes for future thermal power plants is also in doubt at the present time. EPA regulations distinguish cooling lakes from cooling ponds in the following manner: ${ }^{(13)}$ cooling lakes are any manmade water impoundments which impede the flow of a navigable stream; cooling ponds are manmade impoundments which do not impede the flow of navigable streams. Navigable streams are broadly defined to include nearly a 11 natural lakes, rivers, and streams. As noted above, before Appalachian Power v. Train, EPA regulations would have permitted new thermal power plants to discharge heat only in blowdown from cooling towers and cooling ponds. (11) Existing plants would continue to use cooling lakes, but new plants could not. ${ }^{(14)}$ These regulations were set aside in the Appalachian Power case and EPA was directed to consider the impact of any revised regulations on the consumption of water. The court implied that geographically uniform regulations may not be acceptable because the value of water varies by rocation.

Prior to the Appalachian Power decision, EPA had published proposed regulations ${ }^{(15)}$ which if adopted would relieve the restriction on the use of cooling lakes for new thermal power plants somewhat. The regulations have not yet been made final. The proposed regulations would allow the discharge of heat to new on-stream cooling lakes if the lake qualified as a recirculating cooling water body. To qualify, the lake would have to:

1. be environmentally acceptable, 
2. discharge on a long-term average annual basis no more than $2 \%$ of the waste condenser heat,

3. discharge on a long-term average annual basis no more than 100 cfs per $1000 \mathrm{MW}$ generation capacity.

As Table 3 indicates, cooling ponds consume somewhat more water than wet towers. The principal advantage of ponds is their relatively low cost. The principal disadvantage other than water consumption is the large amount of 1 and required, on the order of 1.5 acre/MWe.

\subsection{EVAPORATIVE COOLING TOWERS}

Evaporative cooling towers have become the most common cooling mechanism for recent thermal power plants. Environmental pressures exerted by the AEC (now NRC) and EPA, which have acted under the authority and mandate of the FWPCA and the National Environmental Policy Act, have contributed most to the widespread use of wet evaporative cooling towers. Particular advantages of evaporative cooling towers include less heat discharge to the receiving water body and less total water withdrawal than once-through cooling. Additionally, the large land areas required for cooling ponds and lakes is not needed. Disadvantages include their cost, lower turbine efficiencies resulting in an energy penalty of 2 to 6 percent, formation of fog from the warm, moist effluent and icing of structures near the towers in winter.

\subsection{DRY AND WET/DRY COOLING}

Dry cooling towers utilize large finned-tube heat exchangers with atmospheric air on the outside of the exchangers as the cooling medium. Combined evaporative and dry-cooled systems are commonly referred to as wet/dry systems.

Although dry and wet/dry cooling have been common in Europe in smal1 thermal plants for some time, they have only recently been introduced in the United States. Their principal advantage is low water consumption. Thus they can provide flexibility in power plant siting. In the case of a coal-fired plant, a utility can make an economic trade-off of the cost of transporting coal to a site which would permit wet cooling versus the 
cost of building a mine-mouth plant using wet/dry or dry cooling and transmitting the power. The flexibility advantage is not as important with nuclear plants because the cost of transporting nuclear fuel cycle materials is relatively low, and plant sites can be selected to take advantage of available cooling water. A utility can also compare the cost of locating a dry or wet/dry cooled power plant near a load center to a wet cooled plant farther away from the load center.

Another reason for choosing dry or wet/dry cooling would be to locate a new plant at an existing power plant site which is water constrained. Such location may speed up the licensing process, although this will not always be true (e.g., collocation at the St. Lucie nuclear facilities in Florida has not speeded up the licensing process). A more likely benefit of collocation of power plants is to take advantage of existing transmission corridors, avoid creating a new boom town and at the same time enhance the economic basis of the town created (or enlarged) by construction of the first plant. Certain economies of scale may also be possible, e.g., reduced exclusion area and shared administrative space.

Secondary advantages of dry and wet/dry cooling in relation to all wet cooling are reduced fogging and icing, reduced blowdown disposal, and in the case of coal plants, reduced sulfuric acid problems.

The first large dry-cooled plant in the U.S. is the Wyodak facility near Gillette, Wyoming which came on line in June 1978. (16) The plant is a 330-MWe mine-mouth coal-fired plant jointly owned by Black Hills Power and Light Company and Pacific Power and Light Company.

The first large wet/dry cooled plant in the U.S. is San Juan III under construction northwest of Farmington, New Mexico. Completion is scheduled for summer 1979. The 466-MWe plant, a mine-mouth coal-fired facility, is owned by Public Service Company of New Mexico and Tucson Gas and Electric Company. San Juan IV, also a 466-MWe unit, will also utilize wet/dry cooling unless additional water becomes available to the utilities. Wet/dry cooling was chosen for San Juan III and IV because the utilities wanted to take advantage of an existing, dedicated site and the close proximity of the coal, but were unable to obtain sufficient additional water to utilize evaporative cooling. San Juan I and II, located at the same site, use wet cooling. 

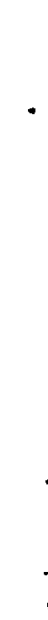


\subsection{ECONOMICS OF COOLING TOWER ALTERNATIVES}

Two crucial elements in estimating the future demand for dry and wet/dry cooling are their cost relative to other cooling options and the physical availability of water. Cost estimates are discussed in this section; water availability is discussed in Section 4.0 .

\section{1 RELATIVE COST OF ALTERNATIVES}

Several recent studies have compared the cost of dry and wet/dry cooling relative to other cooling mechanisms. Based on present relative costs, two principal conclusions emerge. First, without a legal mandate for its use, dry cooling is so expensive relative to other cooling possibilities that it will be only sparingly used in certain isolated areas such as the Wyodak facility near Gillette. The utilities at Wyodak had virtually no cooling water available within a reasonable distance and presumably determined that use of dry cooling would be economically preferable to transporting the coal to a site with sufficient water to utilize evaporative cooling. Second, wet/dry cooling is significantly less expensive than dry cooling, but also considerably more expensive than total wet cooling. It will be used more extensively than dry cooling, but for the most part it too will be utilized most often for mine-mouth plants or to permit siting at an existing power plant site.

A summary of the economic evaluations made in a study ${ }^{(1)}$ conducted by the General Electric Company is shown in Table 5. The costs are for cooling a light water nuclear reactor (LWR) and are in 1975 dollars.

\section{TABLE 5. Water Breakeven Costs ( $\$ / 1000$ gal)}

\begin{tabular}{lccc}
$\begin{array}{c}\text { Plant } \\
\text { Location }\end{array}$ & $\begin{array}{c}\text { Wet Cooling Tower/50-50 Peak } \\
\text { Shaved Dry-Wet Cooling System }\end{array}$ & $\begin{array}{c}50-50 \text { Peak Shaved Dry-Wet Cool- } \\
\text { ing System/Dry Cooling Tower }\end{array}$ \\
\cline { 1 - 1 } Lubbock, TX & $\$ 2.00$ & & $\$ 18.00$ \\
Raleigh, NC & 1.60 & & 32.00 \\
Reno, NV & 1.70 & 53.00
\end{tabular}

SOURCE: Ref. 1. 
Table 5 is interpreted in the following manner: for a LWR in Lubbock, Texas, a 100\% wet cooling tower would be chosen if water costs are below $\$ 2.00 / 1000$ gal. Between $\$ 2.00$ and $\$ 18.00 / 1000$ gal, a $50-50$ peak shaved wet/dry cooling tower system would be the economic choice. When the cost of water exceeds $\$ 18.00 / 1000$ gal, dry cooling is the economic choice.

A study ${ }^{(17)}$ conducted by United Engineers and Constructors estimated that water would have to cost $\$ 4.50 / 1000$ gal (in 1985 dollars or about $\$ 2.50$ in 1975 dollars, assuming $6 \%$ escalation) before wet/dry cooling would be the economic choice over totally wet tower cooling. The calculations in this case were made for a 1000-MWe LWR using meteorological data for Boston.

A 1976 study conducted at the Iowa Institute of Hydraulic Research (18) reached similar conclusions. They concluded the wet/dry cooling becomes competitive with wet cooling at water costs on the order of $\$ 2.00 / 1000 \mathrm{gal}$.

A fourth study conducted by Water Purification Associates concluded that wet/dry cooling becomes competitive with all-wet cooling at water costs of about $\$ 2.40 / 1000$ gal (1975 dollars). (19)

The water breakeven cost estimates in these studies are clearly subject to many assumptions and the reader is referred to the source documents for additional information. All four studies do use the fixed source-fixed demand cost system, whereby each cooling system is compared assuming a fixed electricity demand. Dry cooling reduces the thermodynamic efficiency of a power plant during warm weather. The studies assume that replacement power necessitated by the reduced generating capacity is purchased from fossil-fueled gas turbine peaking units. This penalty cost is added to the cost of dry cooling and to wet/dry systems when operating in the dry mode. Critics of this approach argue that utilities would not really operate in this manner. Instead of purchasing peaking power, they would simply bring on their next power plant somewhat sooner. The appropriate penalty, they argue, is not the cost of peaking power, but the cost of bringing on-line the utilities' next power plant somewhat sooner. Alternatively, an appropriate penalty would be the incremental cost of building a larger capacity 
dry or wet/dry cooled plant. Clearly the magnitude of the penalty using either of these alternatives will be site dependent. Additional study to compare the magnitude of the penalties using all three approaches appears to be warranted.

\subsection{WATER COSTS}

The cost of obtaining, treating, and delivering water in most of the U.S. is below the $\$ 1.60-2.50 / 1000$ gal breakeven point cited in the previous section. The cost of cleaning up agricultural and municipal waste water is also generally less than the breakeven point. Finally, in most cases, it will be possible to purchase farms outright and obtain water rights for substantially less than $\$ 1.60 / 1000$ gal of water. These costs suggest that where water is available within a reasonable distance, it can be purchased, treated and delivered to the plant site at less than the breakeven point and the economic choice will be to use evaporative cooling.

\subsection{WATER PURCHASE}

The cost of purchasing fresh water ranges from virtualiy zero to as much as $\$ 0.60 / 1000$ gal for municipal water in California. (1) In most cases someone exercising a riparian or appropriate water right merely has to pay for the improvements necessary to divert the water. The cost of the water is zero. The Bureau of Reclamation simply requires farmers to repay its cost of delivery. Usually the annual cost to the farmers is under $\$ 20 /$ acre-ft ( $\$ 0.06 / 1000 \mathrm{gal})$. On the Columbia Basin Project in Washington State, for example, it ranges from about $\$ 5.00-\$ 7.00 /$ acre-ft. Private irrigation districts generally also charge their delivery costs. The cost of the water varies with the age of the irrigation district and the extent to which the diversion improvements have been paid off. Dr. Alfred Marsh, Extension Irrigation and Soils Specialist at the University of California at Riverside, indicated to the author that farmers in the Imperial Valley Irrigation District in Southern California pay as little as $\$ 5 /$ acre-ft because the district is long established. He also indicated that farmers 100 miles away in southern San Diego County currently pay 
up to $\$ 150 / \mathrm{acre}-\mathrm{ft} / \mathrm{yr}(\$ 0.46 / 1000 \mathrm{ga} 1)$, probably the highest irrigation cost in the country. The high cost results in part because the district is relatively new and because there are high energy costs to deliver the water.

\subsubsection{Water Treatment and Delivery}

Water treatment, blowdown disposal, and delivery costs (1975 dollars) were estimated for six potential power plant sites in the Water Purification Associates study. (19) Water purchase costs are not included. The results are shown in Table 6 . The Gillette, Wyoming site is the highest cost site by far. The pipeline in this case would be 170 miles long and rise 2000 feet in elevation. This cost suggests a trade-off between wet and wet/dry cooling. As noted earlier, the Wyodak dry cooled plant has recently begun operation near Gillette. The top line for the Kaiparowits site is for a 45-mile supply line rising 2780 feet in elevation. The bottom 1 ine is for a 25 -mile line rising 2100 feet.

TABLE 6. Water Treatment and Supply costs for Six Power Plant Sites

\begin{tabular}{l|c|c|c}
\multirow{2}{*}{ SITE } & \multicolumn{3}{|c}{ Evaluated water Costs } \\
(\$/1000 gallons of water evaporated $)$
\end{tabular}


Water delivery costs for energy projects in North Dakota, Wyoming, and Montana were estimated in the Northern Great Plains Resources Program report. ${ }^{(20)}$ Average annualized delivery costs (1973 dollars) ranged from $\$ 38 / a c r e-f t(\$ 0.12 / 1000$ ga 1$)$ for North Dakota under a low energy growth assumption to $\$ 147 /$ acre-ft $(0.45 / 1000$ ga 1$)$ for Montana and Wyoming under medium and high energy growth assumption. The same study indicated that where ground water is available in Montana and Wyoming it could be delivered at an annualized cost of about $\$ 50 /$ acre- $\mathrm{ft}$.

\subsubsection{Municipal Waste Water}

The use of treated municipal sewage water for power plant cooling is an increasingly attractive option. A principal advantage is that it provides an assured source of supply. Southwestern Public Service Company has been using municipal waste water to cool plants near Amarillo, Texas for 15 years and plants near Lubbock, Texas for 4 years. (21) The Nevada Power Company began using sewage water to cool small gas/oil-fired plants in 1955. It is planned that the 1500-MWe Harry Allen coal-fired power plant complex will use sewage effluent from the city of Las Vegas. (22)

Six southwestern utilities building three pressurized water nuclear reactors of approximately 1270 MWe each will use municipal sewage water for cooling. The reactors, designated the Palo Verde Nuclear Generating Station, will be located about 36 miles west of Phoenix. The sewage water to be used will have secondary treatment. The utilities will further treat the water before using it for cooling. The final environmental impact statement for the plants ${ }^{(23)}$ indicates that use of wet/dry cooling rather than wet cooling would add $\$ 39,109,000$ to the total annualized cost of the three plants and reduce average water consumption by $16,050 \mathrm{gpm}$. This suggests that water would have to cost $\$ 4.63 / 1000 \mathrm{gal}$ ( $\$ 1509 / \mathrm{acre}-\mathrm{ft}$ ) before wet/dry cooling would be the economic choice. These costs must be used with caution because the statement does not indicate what year dollars are utilized for the computations.

Municipal sewage water was considered for use at the Rancho Seco Nuclear Unit No. 2, about 25 miles east of Sacramento, California. The cost of 
conveying and treating the water was estimated to be $\$ 358 /$ acre-ft $(\$ 1.10 /$ $1000 \mathrm{gal})$. (24) The alternative was rejected in this case because much less expensive (\$16/acre-ft) water was available from the Folsom Canal.

\subsubsection{Agricultural Waste Water}

The cost of treating highly saline agricultural waste water for power plant cooling is also appreciably less than the breakeven water costs indicated in the preceding section. A recent study conducted by the California Department of Water Resources estimates the cost of treating highly saline agricultural waste water in the San Joaquin Valley of California for power plant cooling. Excluding brine disposal, the authors of the study estimate that 11.5 million gallons per day of waste water can be treated for $\$ 0.34$ per 1000 gal in 1976 dollars. (25) In an earlier study conducted by Kaiser Engineers, and cited in the california study, brine disposal costs were estimated to be $\$ 0.19 / 1000$ gal (1976 dollars) with evaporation ponds only and $\$ 0.52 / 1000$ gal (1976 dollars) with a brine concentrator followed by small evaporation ponds. Total treatment and disposal costs are thus likely to be less than $\$ 1.00 / 100 \mathrm{gal}$.

\subsubsection{Irrigated Farm Purchase}

Finally, it is worthwhile to consider what it would cost a utility to obtain water rights by purchasing irrigated farm(s) outright. It appears that water could also be obtained in this way at less than the breakeven cost for selecting wet/dry cooling. Examination of the Farms and Ranches classified sections of the Friday editions of the Wall Street Journal reveals that irrigated western farms have asking prices in the range of $\$ 1000-\$ 4000 /$ acre Typically, farmers have rights to apply 3-6 ft of water per acre per year. A utility purchasing a farm would only obtain the consumptive water rights of the particular farmer. Water not consumed in growing the particular crop either percolates into the ground water or is carried away as surface runoff and in many cases is reapplied to downstream land. Mr. Mel Hagood, Irrigation Specialist for the Washington State Extension Service in Prosser, Washington, indicated to the author that in the Columbia Basin Project of Washington State, irrigation efficiencies (i.e., water consumed/water withdrawn $\times 100 \%$ ) are 
about $43 \%$ for surface application and $64 \%$ for sprinkler irrigation. Efficiencies elsewhere in the country vary with water cost, the climate, soil, and type of irrigation equipment. In areas where water costs are very high (e.g., San Diego County), drip irrigation is frequently used and irrigation efficiency can be as high as $90 \%$.

In many cases a utility purchasing an irrigated farm for the water right will want to retain the 1 and. The land will provide a productive use for the water when it is not needed. This could be during construction and/or downtime. Moreover, a utility will likely want to purchase sufficient irrigated farms and/or water rights so that it is assured of adequate cooling water in the driest foreseeable year. Excess water in wet years can be applied to the farm. Irrigation when the water is not being used for cooling should also prevent a claim by a third party that the water right has been abandoned or forfeited for nonuse.

Table 7 shows the cost of water acquired by farm purchase under representative assumptions. The total water cost in the far right column appears to be relatively moderate when compared to the breakeven costs for wet/dry cooling.

TABLE 7. Cost of Water Acquired by Purchasing Irrigated Farms

\begin{tabular}{|c|c|c|c|c|c|c|c|}
\hline Case & $\begin{array}{l}\text { Land Cost } \\
\text { (\$/acre) }\end{array}$ & $\begin{array}{l}\text { Feet of } \\
\text { Water } \\
\text { per Acre }\end{array}$ & $\begin{array}{l}\text { Irrigation } \\
\text { Efficiency }\end{array}$ & $\begin{array}{c}\text { Taxes } \\
\$ / \text { acre/yr }\end{array}$ & $\begin{array}{c}\text { Holding } \\
\text { Cost } \\
\$ / \text { acre/yr }\end{array}$ & $\begin{array}{r}\begin{array}{r}\text { Total } \\
\text { Cos }\end{array} \\
\text { \$/acre-ft }\end{array}$ & $\begin{array}{l}\text { Water } \\
t \\
\$ / 1000 \mathrm{gal}\end{array}$ \\
\hline A & 1500 & 3 & $40 \%$ & 15 & 60 & 62.5 & .19 \\
\hline B & 2000 & 4 & $45 \%$ & 20 & 80 & 55.6 & .17 \\
\hline$C$ & 3000 & 4 & $55 \%$ & 30 & 120 & 68.2 & .21 \\
\hline$D$ & 4000 & 4 & $60 \%$ & 40 & 160 & 83.3 & .26 \\
\hline
\end{tabular}

Real estate taxes in column 4 are calculated as $1 \%$ of farm cost. In some parts of the country this will be somewhat low. On balance it seems a reasonable approximation because the market value of the land will decline when it is no longer being irrigated.

Column 5 indicates the holding cost for the 1and. This is calculated as $4 \%$ of market value for the 1 and. The $4 \%$ figure represents the difference 
between the utilities' opportunity cost (assumed to be 10\%) and the land value escalation rate (assumed to be $6 \%$ ). The opportunity cost of an investor-owned utility will exceed 10\% under today's financial conditions, however, it will 1ikely be less than 10\% for a non-investor owned utility.

Omitted from the Table 7 analysis are net farm revenues from crop production and/or animal grazing and an allowance for future federal income taxes due from an investor-owned utility if the farm is ever sold. As a rough approximation these can be assumed to cancel each other.

Beyond the purchase cost, the utility would have to pay the annual delivery assessment, which as noted earlier is usually less than $\$ 0.10 / 1000$ gal, but could range as high as $\$ 0.40 / 1000$ gal. Additional costs could be required for water treatment and diversion equipment. A utility may also have to build a water storage basin if its water rights are sufficiently unreliable that it could run out of water in low water years, such as the Western states experienced in 1977. Occasionally a water storage facility may also be required to consume water during months when the land was not previously irrigated. Construction of a storage basin for the latter reason only may not be needed if water supply is not a problem in winter months and water is available for consumption, if adequate storage on the stream al ready exists, ${ }^{(27)}$ or if storage in underground basins is possible. (28)

The fact that the Table 7 water cost figures suggest utilities can purchase irrigated farms outright to put the water to an alternative use should not be too surprising. Prior studies have estimated the long-run value of water for irrigation in the West to be in the $\$ 15-\$ 40 /$ acre-ft range at the farmer's headgate. (29) The average value of water for irrigation in Maricopa County, Arizona, site of the Palo Verde Nuclear Generating Station, was estimated to be less than $\$ 0.50 /$ acre-ft $(\$ 0.15 / 1000 \mathrm{gal})$, with a maximum value of $\$ 370 /$ acre-ft $(\$ 1.13 / 1000 \mathrm{gal})$ ( $^{(30)}$ 


\subsection{CRITICAL WATER AVAILABILITY AREAS}

The analyses in the preceding section suggest that when water is physically available and can be acquired by purchase or otherwise, a utility would normally select wet cooling over wet/dry cooling towers. This section briefly addresses the question of availability of water. The principal conclusion is that sufficient water is available to utilize wet evaporative cooling towers for projected thermal power plants in most sections of the country through the year 2000. Certain sections of the country, especially the Southwest, will experience physical shortages and can be expected to utilize some wet/dry cooling.

\subsection{WATER AVAILABILITY AND CONSUMPTION IN THE U.S.}

Absolute water scarcity is not likely to become a problem in the U.S. in the foreseeable future. The mean annual runoff in the continental U.S. is 1200 billion gal per day (bgd). Current storage capacity provides about 280 bgd in dependable surface supply. An additional 83 bgd are withdrawn from underground water sources and 69 bgd from surface saline water supplies. (31) In spite of this water abundance, shortages do occur and will continue to occur because the water is not uniformly spread throughout the country. Interbasin water transfers are often prohibitively expensive, especially if they involve long distances.

The most recent projections of water supply and consumption in the U.S. are in the Second National Water Assessment under preparation by the U.S. Water Resources Council. A preliminary version of the Assessment was issued for review in April 1978. Section 3 of the draft summary volume to the Assessment indicates that two of the 18 water Resource Council regions can be expected to have serious water supply problems. These regions are the lower Colorado and the Rio Grande.

By far the greatest use of water in this country is for agriculture. The U.S. Geological Survey ${ }^{(31)}$ estimates that 96 bgd of fresh water were consumed in the U.S. and Puerto Rico in 1975. Of this amount, 80 bgd (83\%) were consumed for irrigation (an additional 23 bgd was lost during conveyance), 6.7 bgd (7\%) for public supplies, 3.4 bgd (4\%) for rural use, 1.9 bgd $(2 \%)$ for steam electric power use, and 6.1 bgd (6\%) for self-supplied industrial use. 
Using data in Tables 1 and 3, cooling water consumptive requirements in the year 2000 can be calculated. A high estimate can be made by assuming that all cooling is done by mechanical draft wet cooling towers. Using this assumption, the total consumptive water requirement under the ERDA projection is $14.15 \mathrm{bgd}$; the UWAG projection requires $34.30 \mathrm{bgd}$.

The greatest competition for fresh water is likely to occur in the 11 westernmost states of the continental U.S. These are the states where rainfall is the lowest and irrigation is most intensive. The Westwide study, citing projections made by the Western Systems Coordinating Council, estimated that $2.5 \mathrm{M}$ acre-ft annualiy of fresh and waste water potentially will be consumed to meet cooling requirements in the 11 states by the year 2000 . To put this figure in perspective, the estimated fresh water consumption for irrigation in 1975 in these 11 states was $57 \mathrm{M}$ acre-ft. (31)

\subsection{REVIEW OF STUDIES ESTIMATING THE DEMAND FOR WET/DRY COOLING}

At least two studies have considered the physical supply of water by region throughout the United States and then estimated the demand for wet/dry cooling through the year 2000.

The first study, prepared by the General Electric Company, (1) projected that the geographic areas facing the most critical water shortages for thermal power plant cooling would be the Texas Gulf region, California, and the upper and lower Colorado River basins. It projected that in the Texas Gulf and California regions, sufficient water for wet cooling could be found from waste, ocean, or ground water and that wet/dry cooling could thereby be avoided. In the Colorado River Basin it projected that thermal power plants coming on line between 1985 and 2000 would potentially require wet/dry cooling. Using data in Table 1, this means that 6 to 23 GWe of nuclear power and 5 to 19 GWe of fossil-fired power plants could require wet/dry cooling through the year 2000 , depending on the rate of power growth. The total projected need is thus 11 to 42 GWe. In making this projection the G.E. authors assumed no water transfer from irrigation to power plant cooling. If such transfer occurs, which seems likely to this author, the demand for wet/dry cooling would be at the lower end of the ranges regardless of the rate of electricity consumption growth. 
-

-

• 
these considerations to the G.E. and HEDL estimates, it seems reasonable to expect that approximately 20 GWe of wet/dry cooling will be required primarily in the Southwest by the year 2000 .

\subsection{REGIONAL PROJECTIONS OF WATER AVAILABILITY FOR COOLING}

A number of regional studies have been prepared regarding the availability of water for general energy development. Some of them are reviewed in this section.

\subsubsection{Colorado River Basin}

The Colorado River system is subject to two important allocation laws. The 1922 Colorado River Compact assures Arizona, California, and Nevada a combined allocation of at least $75 \mathrm{M}$ acre-ft of water in each successive 10-year period. There is no fixed annual water commitment under the compact. The Mexican Water Treaty of 1944 assures Mexico an annual amount of $1.5 \mathrm{M}$ acre-ft, except in times of extreme shortage. There is essentially no additional outflow from the region except for this $1.5 \mathrm{M}$ acre-ft.

Both the G.E. and HEDL studies projected a need for wet/dry cooling in the Colorado River Basin. On an overall basis for the western states, it appears that the key element in determining the extent of the need will be the extent to which agricultural water rights can be obtained and transferred in sufficient quantity and in appropriate locations to permit completely wet cooling. Of course, a utility could still decide that site specific locational factors suggest wet/dry cooling for other reasons. Further discussion regarding obtaining agricultural water rights is in Section 5.0 .

\section{Upper Colorado River Basin}

The Department of the Interior released a report ${ }^{(35)}$ in 1974 which projected water use from the Colorado River for Colorado, New Mexico, Utah, and Wyoming. Figure 1 is reproduced from this report. The study assumes that $5.8 \mathrm{M}$ acre-ft should be available to the four states on a continuing 


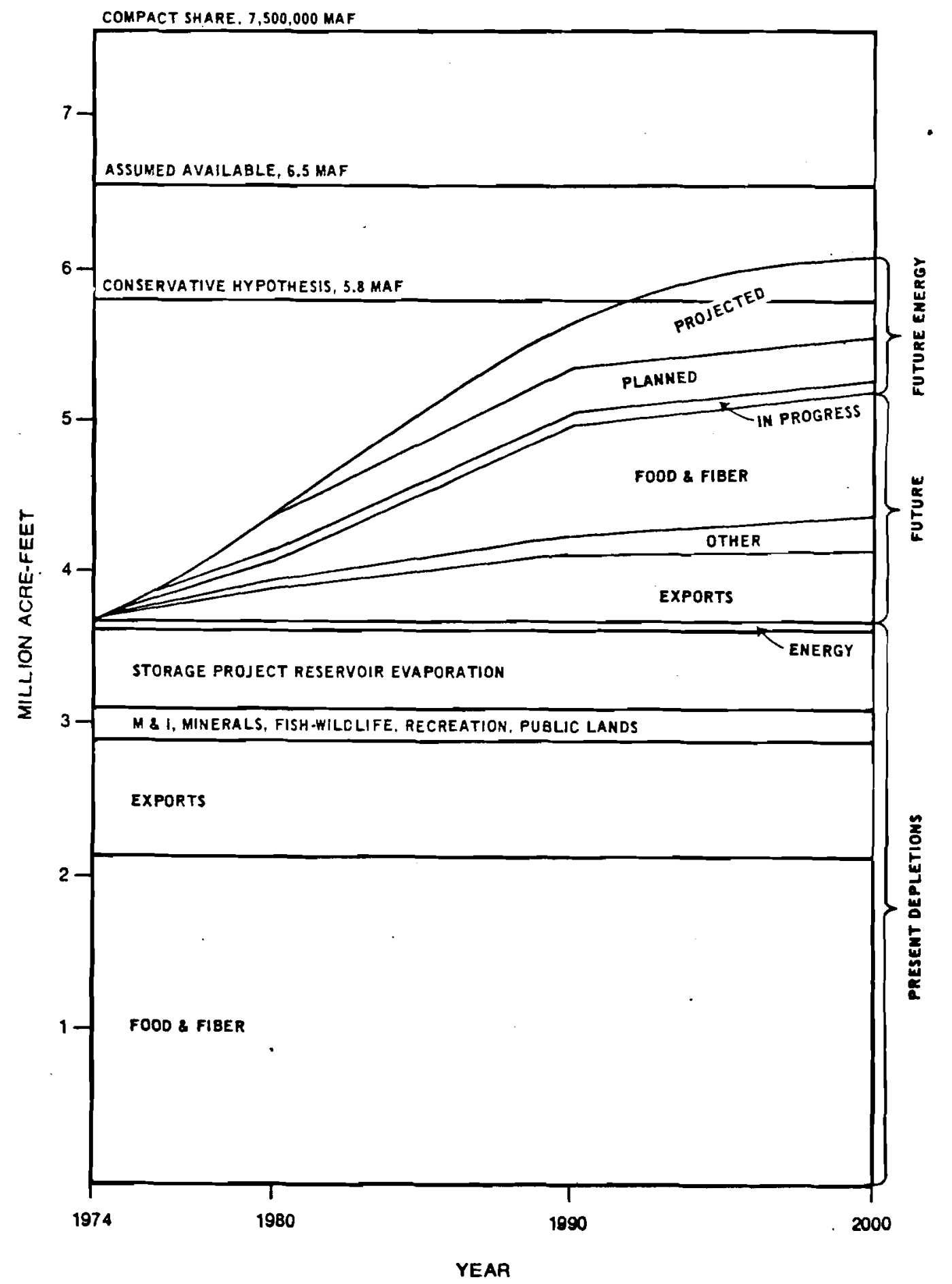

FIGURE 1. Upper Colorado River Basin Water for Energy, 1974 to 2000

SOURCE: Ref. 35. 
basis. (a) Other assumptions inherent in Figure 1 are: 1) no wet/dry or dry cooling, 2) no weather modification, 3) some ground water withdrawal, and 4) minimal transfer of water from agricultural use to other uses. With these assumptions water use reaches $5.8 \mathrm{M}$ acre-ft about 1991. If water for agriculture is made available for energy, this date can be extended further into the future. Transfer seems likely because of the economic reasons discussed in the preceeding section and because the four states have no significant restrictions on the transfer of water rights, as will be discussed in the next section.

\section{Lower Colorado River Region}

The future water supply picture in the lower Colorado region is potentially more critical than in the upper Colorado region. The region is currently utilizing all available surface flow and is mining ground water at the rate of about 2.7 million acre-ft per year. Ground water levels are currently declining on the order of 8 to 10 feet per year in south central Arizona. Completion of the Central Arizona Project and the Southern Nevada Water Project will alleviate the problem somewhat. Nevertheless, at some future time it will become prohibitively expensive for agricultural users to continue to extract ground water.

The U.S. Water Resources Council projects in the preliminary draft of the Second National Water Assessment that al1 thermal power plant capacity in the region after 1985 will be dry or wet/dry cooled. State and regional projections in the draft Assessment assume continued use of wet cooling.

\subsubsection{Rio Grande River Basin}

The Rio Grande Region is one of the most water scarce areas in the U.S. The existing water supply is essentially fully appropriated. About ninety percent of 1975 fresh water consumption of 3500 million gallons per day for mean annual conditions is utilized for irrigation.

\footnotetext{
(a) There is some evidence that this figure may be optimistic. Analysis performed by the U.S. Geological survey suggests that the dependable annual supply (sustainable $98 \%$ of the tjme) of the entire Colorado River system is only 12.7 million acre-ft. $(36)$ On an average basis, 8.25 million acre-ft may have to be delivered to the Lower Basin States leaving only 4.5 million acre-ft for the upper basin.
} 
In $1975,10,638$ gigawatt hours of electricity were produced in the region, all from fossil sources. Data in Table 1 suggest growth in fossil-generated power but not nuclear. The preliminary copy of the Second National Water Assessment projects for the year 2000 a decline in fossil based electricity production to 3140 gigawatt hours and 23,360 gigawatt hours of nuclear based generation. The U.S. Water Resources Council expects that most of the new generating capacity will be dry or wet/dry cooled. State and regional officials project continued wet cooling, but without water transfer from irrigation. Mechanical draft wet cooling of all projected generation in the year 2000, would consume on the order of $47 \mathrm{mgd}$ which is about $1.5 \%$ of current consumption for irrigation. Unless significant restrictions on water transfer are introduced, it seems reasonable to conclude that at least some of the new capacity can be wet cooled.

\subsubsection{Upper Missouri River Basin}

The Upper Missouri River Basin has considerably more water available for energy development than the Colorado River system. The U.S. Department of the Interior reached the following conclusion:

"The total unallocated water supply in the Upper Missouri River Basin appears to be ample, through the year 2000, to meet all projected needs including a high degree of energy development. However, in the Yellowstone subbasin there is a problem of distribution of supply from point of origin to point of potential need." (37)

The Northern Great Plains Resource Program study ${ }^{(20)}$ reaches a similar conclusion. The main stem of the Missouri River has an abundance of stored water, much of which is available for allocation. Although the Big Horn River is the orly major stream in the Yellowstone Basin with significant storage capacity at the present time, the study concludes that there is sufficient storage in the Basin to supply the needs of coal development to the year 2000. This conclusion assumes evaporative cooling for all coalfired thermal power plants. A study prepared by the Montana Department of Natural Resources and Conservation ${ }^{(38)}$ basically agrees with this conclusion but adds as a caveat that "two of the tributaries (of the Yellowstone River), 
the Tongue and the Powder, are not, under current conditions, dependable sources for appropriation for additional continuous, year-round use or even for the full irrigation season." A moratorium on water applications from the Yellowstone River for new water rights of $20 \mathrm{cfs}$ or greater, reservoirs with a capacity of 14,000 acre-ft or more, and transfers to other than agricultural use has been in effect since 1974.

The western Dakota tributaries of the Missouri River can provide only minimal amounts of water when compared to the main stem Yellowstone or Missouri Rivers. (39)

\subsubsection{California}

The water supply picture in California is complicated by two important factors. Power plant sites on the California coast have access to abundant ocean water for cooling. However, location on the coast is difficult for a number of reasons, particularly seismic, environmental and aesthetic concerns. Use of water for cooling inland power plants is complicated by the policy statement of the California State Water Resources Control Board. (40) Principle 1 of the Board's policy statement is that water for thermal power plant cooling should come from the following sources in order of priority: 1) waste water being discharged to the ocean, 2) ocean water, 3) brackish water from natural sources or irrigation return flow, 4) inland waste waters of low total dissolved solids, and 5) other inland waters. Principle 2 states that use of fresh inland waters for cooling will only be approved when it is demonstrated that other water sources would be "environmentally undesirable or economically unsound". These policies, plus the opposition of the California Farm Bureau Federation to transfer of water from agricultural use, suggest that some wet/dry cooling is inevitable in California over the next 20 years. The HEDL projection of wet/dry cooling in California may thus be more accurate than the G.E. projections.

Currently power plant cooling in California consumes 32,000 acre-ft/yr of water. (41) The state estimates that if all proposed inland power plants utilize wet cooling, about 800,000 acre-ft/yr will be required by 1995 . (42) The state's present annual water demand is $37 \mathrm{M}$ acre-ft; irrigated agriculture takes $85 \%$ of the demand. Ground water provides $40 \%$ of the state's demand; however, the current overdraft is about $2.2 \mathrm{M}$ acre-ft/yr. 
The Colorado Desert hydrologic area within California is identified by the state as having the greatest potential for pressure on water resources. Cooling water demand in this area could reach 340,000 acre-ft/yr by 1995. This figure represents about $20 \%$ of current agricultural use. ${ }^{(43)}$ The Colorado Desert hydrologic area does, however, have considerable agricultural waste water that is potentially available for thermal power plant cooling. About 400,000 acre-ft/yr of irrigation drainage water returns to the Colorado River from the Palo Verde Valley outfall drain. (44) The San Diego Gas and Electric Company wanted to consume about $34,000 \mathrm{acre}-\mathrm{ft} / \mathrm{yr}$ of this water to cool its two proposed Sundesert nuclear plants near Blythe. (a) In addition to the Palo Verde waste water, about $1.3 \mathrm{M}$ acre-ft of primarily agricultural waste water enters the Salton Sea each year. Nearly $1.0 \mathrm{M}$ acre-ft of this total is irrigation waste water from the Imperial Valley. ${ }^{(44)}$

(a) The preliminary report of the California Energy Resources Conservation and Development Commission, 76-NOI-2, issued April 14, 1977 requested the utility to submit in subsequent hearings a "comparative cost/benefit analysis" of wet/dry versus wet cooling for the; two units. The Commission declined to approve the plant in February 1978 principally because of concerns about nuclear waste disposal. The state legislature has not chosen to override the decision. The Wall Street Journal, September 12, 1978, p.1, col.8. 


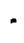

.

. 


\subsection{ALTERNATIVES FOR ACQUIRING INLAND WATER AND ASSOCIATED DIFFICULTIES}

Five alternatives for acquiring inland water rights are discussed in this section: exercise of appropriation and riparian rights, acquisition of water from Federal water projects, the purchase of water from private owners and water districts, and the pumping of ground water. Difficulties associated with each type of acquisition are discussed.

\subsection{APPROPRIATION}

Most of the states where water allocation problems are likely to occur follow the appropriation system of water rights. There are 18 appropriation states. They include North Dakota and Texas, and all states on the line between and west thereof except Hawaii. Certain states (e.g., Utah, Nevada, and Idaho) have rejected most riparian concepts (see section on riparian rights). Other states (e.g., Texas, California, and Washington) recognize certain riparian rights.

The essence of the appropriation system of water rights is stated in the following quotation from the Summary-Digest of State Water Laws prepared for the National Water Commission.

"The barest essence of the law of appropriation is that a water right is acquired by diverting water from a natural watercourse and applying it to a beneficial use. The water right carries a 'priority' date, which is the date that the first act was done to initiate the right, and the consequence of the priority date is that the water right will have a superior call upon the watercourse over all rights subsequently initiated. When a stream becomes over appropriated, so that the call upon the stream is in excess of the water in it, then the owner of the oldest water right is first entitled to his full delivery of water, and then the next oldest right is fully satisfied, and so on down the line until the water supply is exhausted -and those with the most recently acquired rights get no water at a11."(45)

Application for new water rights is generally made to a central state office, often the State Engineer. Until relatively recently the only criterion utilized by the engineer in processing new applications was whether unappropriated water was available. A number of additional public interest criteria have 
been added to the priority criterion by state legislatures in recent years. These include whether instream uses, fishery resources, water quality, vegetation, and aesthetic amenities will be protected. Alaska, ${ }^{(46)}$ California, and Oregon ${ }^{(48)}$ for example, have passed legislation providing for some form of public interest standard for the water administrator to consider in issuing new water rights. In Nevada, the State Engineer is allowed to consider the state's public interest and economic welfare in reviewing applications to appropriate or change the use of water for generating electricity to be exported out of state. (49) South Dakota requires applications for the appropriation of over 10,000 acre-ft/yr to be submitted to the state legislature. (50) The 1976 Utah legislature authorized the State Engineer to put a time limit on industrial water appropriations. At the expiration, the water would revert to the state. Montana passed legislation in 1977 which excludes use of water for interstate coal slurry pipelines from the definition of beneficial use. (51)

Appropriation of water for use outside a state is difficult. Some states prohibit such appropriations absolutely. In the other states, applications for out-of-state use are likely to be found to be contrary to the public interest. Some interstate river compacts, e.g., the Yellowstone River Compact, prohibits export of waters outside the river basin.

Except for water acquired from Federal reclamation and storage projects, acquisition of new water rights in the West is not likely to be a significant source of cooling water in the future. This is because in many Western states, streams are fully appropriated and the paper water rights exceed the yield of the watercourses. Utah, Nevada, New Mexico, Arizona, and much of Colorado and Montana fall in this category. (52) In states where water is not fully appropriated, a utility may not be able to acquire rights of sufficient quantity and seniority to meet its cooling needs.

\subsection{EXERCISE OF RIPARIAN RIGHTS}

Riparian water rights arise by virtue of ownership of real property bordering natural water courses. (45) The riparian water right is the right to make a reasonable use of the water. Reasonableness is not subject to 
precise definition, but depends on a variety of factors, including the nature of the use and the quantity of water in the watercourse. Traditional riparian water use is characterized by many uncertainties regarding the nature, extent, and scope of existing uses and the quantity of water available for new uses. Another element of uncertainty is what land the water can be used on. Traditionally water could be used only on riparian land, i.e., land adjacent to the waterway. This rule has been relaxed in some jurisdictions, but the criteria used to determine where water can be utilized are often inconsistent. These elements of uncertainty are particularly undesirable for a utility seeking water for cooling.

Because of the uncertainties associated with traditional riparian rights, many Eastern states have adopted water permit systems. The systems differ from state to state; however, permits are usually administered by a central state agency and are issued only if existing riparian and permit uses are not adversely affected. (45) Thus an element of priority does usually exist in permit systems.

\subsection{ACQUISITION FROM FEDERAL WATER PROJECTS}

Acquisition of water from the large Federal water resource projects is perhaps the most likely source of cooling water. In the West, it is usually acquired from Bureau of Reclamation projects or the Corps of Engineers and in the East from Corps of Engineers projects. Prior Bureau policy was apparently to acquire a state water right for all water to be stored in the reservoir and then sell the water to water districts and others. (45) In recent years the states have been allowed to participate more actively in marketing the water from Bureau projects. Mr. William Crosby, a water marketing official with the Bureau of Reclamation in Billings, Montana indicated to the author that the Bureau now requires water applicants to obtain state approval before a water right is issued. In two recent instances the Bureau has alloted 300,000 acre-ft of water directly to Montana and South Dakota for subsequent allocation. The water is from storage reservoirs on the main stem of the Missouri River. The Corps apparently has always required water applicants to acquire their actual water rights under state law. (45) 
The principal general authority for the Bureau of Reclamation to sell water for industrial purposes is the Reclamation Project Act of 1939 (43 U.S.C. $\$ 4851(c)$ ) and the Water Supply Act of 1958 (43 U.S.C. §3906). A Federal District Court in Montana ${ }^{(53)}$ cited this authority as one reason for allowing the Bureau to market water for industrial purposes out of the Yellowtail and Boysen Reservoirs, located in Montana and Wyoming. The plaintiff in the case argued that Congress had not authorized the construction of the reservoirs for the purpose of marketing water to industrial users.

As discussed elsewhere in this paper, there are significant economic incentives to transfer irrigation water to use for power plant cooling. The ability to transfer water authorized for irrigation by the Bureau of Reclamation is somewhat unclear. Since about $25 \%$ of the irrigated 1 and in the Western states is supplied with water from Bureau of Reclamation projects, transferability is an important issue. (54) In basins such as the Missouri, where significant unallocated water exists, transfer of Bureau water al10cations will not be a problem in the near future. In other basins, such as the Colorado, it is already an important issue.

Frank Trelease, Professor of Law at the University of the Pacific, makes the following statements ${ }^{(54)}$ regarding the transfer of water allocated by the Bureau of Reclamation.

"In genera1, there is no express restriction in Federal law against transfers, and although water rights are made appurtenant to 1 and and one landowner may not by purchase or otherwise irrigate more than 160 acres, these provisions do not seem to add up to a prohibition of sales. Practically a11 Bureau of Reclamation repayment contracts, however, require the consent of the Bureau to any transfer of water rights. Officials of the Bureau have generally had a strong policy against transfer of project water by owners of irrigated 1 and. Their reluctance is based in part on the theory of preventing windfal1 profits that would accrue to the farmer who reaps the irrigation subsidy in such case, in part on the fear of jeopardizing repayment. Since no firm policy has been established at the national level, in most areas transfers are discouraged, but in others, as in the Northern Colorado Conservancy District, there is an active market in project water." 
In a study prepared for the National water Commission in 1970, Meyers and Posner found no opposition from top Bureau of Reclamation officials to the transfer of water from irrigation to industrial use. They speculated, however, that regional officials may resist such transfers.

The final report of the National Water Commission recommends that transfers of water rights obtained through Federal agencies be permitted as long as payment of the transferor's financial obligation to the Federal agency is assured. (56)

\subsection{TRANSFER OF STATE WATER RIGHTS}

The acquisition of water that is currently being used for alternative uses is likely to be an important source of cooling water in the future. This will be especially true in the West where many streams are already fully appropriated.

Permanent transfer of rights will normally be desired by a utility seeking water for cooling. In some cases, however, a temporary transfer may be desired. For example a utility may want to have access to very senior water rights in unusually dry years. An agreement might be negotiated with a farmer to purchase his water only in abnormally dry years. (a)

Assembling water rights for a new use is a complicated process. The procedures to be followed are generally set out in statutes and case law, and differ from state to state. Many of the generic problems that exist are identified and discussed in an article by Richard Dewsnup. (27) His article is specifically addressed to water rights in Western states; however, many of the problems apply in Eastern states as well. Among the problem issues he identifies are the following:

(a) This type of agreement has been successfully utilized. See E. W. Clyde, "Legal Overview - Current Problems in Water Acquisition," presented at the Institute On Water Acquisition for Mineral Development sponsored by the Rocky Mountain Mineral Law Foundation, University of Colorado, March 1978. 
1) Existing water rights may be unrecorded.

2) Recorded water rights may be incomplete and inaccurate. The amount of return flow associated with the water right is often not quantified. This is especially significant to a utility, because it affects the amount of water available for evaporative cooling consumption.

3) The recorded "paper rights" often exceed the amount of water physically needed by the water right holder.

4) Some water rights appearing on the record as valid may be imperfected or lost as a result of abandonment, forfeiture, or prescription.

Particular issues important to water transfers under the appropriation and riparian systems and for water irrigation districts are discussed in the following subsections.

\subsubsection{Appropriation System}

Generally, western water rights are treated as salable property rights. Rights are granted in perpetuity, but can be transferred to accommodate new uses. Transfer of water rights normally must be approved by the state water rights administrator. The transferor may only transfer the water rights he owns. The general, but not universal, rule is that transfers to new users and new uses is allowed as long as no other appropriator is injured thereby. Changes in diversion point are generally allowed as long as other appropriators are not injured.

Water rights can be sold separately from the land and utilized on other lands with in the state in all appropriation states except Nevada, Oklahoma, and South Dakota. ${ }^{(58)}$ In these states the water right remains appurtenant to the land on which it is used. The restriction in these three states is significant because in most cases the power plant would not be located on the acquired 1and. In Nevada the restriction apparently applies to all water rights; in the other two states it applies to irrigation rights only. The three states do provide that water rights may be transferred if it becomes economically "impracticable" to continue using the water on the land. This exemption is unlikely to be helpful, however, to a utility seeking water. 
Transferors can only transfer the rights they have. Their rights are measured not only by the quantity of water withdrawn, but the timing of withdrawals and the percentage of water withdrawn that is consumed. Thus, as mentioned earlier, a power company purchasing an irrigation water right may have to provide storage in order to consume water in nonirrigation seasons. If no storage on the stream exists, water in the nonirrigation seasons may be available for appropriation. If storage does exist, the utility can perhaps arrange to have its summer water consumptive right allocated on a prorata basis throughout the year.

Several states have adopted use change criteria which directly or indirectly inhibit the possibility of transferring water to cooling use. Several of them are significant and can directly affect the demand for wet/dry cooling. They appear to have resulted from the political strength of agricultural and environmental interests. A principal concern appears to be the fear that community infrastructures based on an agricultural economy will be significantly disrupted by water transfers.

As discussed in Section 4, California has a policy of not approving the use of fresh inland water for thermal power plant cooling. This policy apparently applies both to new appropriations and to water use changes.

This restriction probably reflects, in part, efforts by the California Farm Bureau Federation to restrict the transfer of water from agricultural to industrial use. The California Federation has adopted the following resolution. (59) 


\section{No. 47}

\section{Electrical Power Generation}

"High quality fresh water in California is insufficient to meet anticipated demands for domestic, industrial, and food production purposes.

Water of a quality which makes it useful for agriculture and domestic consumption should be protected for those uses. Cooling water for electric power generators should be supplied by sources in the following order of priority:

1. Ocean water

2. Waste water which would otherwise be discharged to the ocean.

3. Drainage water not suitable for agricultural, domestic, or industrial reuse.

Cooling tower vapor emissions may be detrimental to crops. Storage ponds for water supplies and blowdown disposal should displace a minimum of land capable of producing food."

The California Farm Bureau opposed the use of Palo Verde outfall drain water for cooling at the proposed Sundesert Plant of San Diego Gas and Electric. Their position is that the water is still sufficiently fresh that it can be used for further irrigation. Other state farm bureaus do not take the same position as the California Farm Bureau. Farm Bureau offices in Arizona, Utah, and Colorado contacted by the author all advocated no restrictions on water rights transfers. They did, not suprisingly, prefer free market transfers to condemnation.

Montana amended its Water Code in 1975 to prohibit the changing of an agricultural water right to an industrial use if the quantity of water exceeds 15 cubic feet per second (cfs). (60) There is no apparent restriction, though, on a utility accumulating water rights each of which is less than $15 \mathrm{cfs}$.

North Dakota passed legislation in 1977 providing that water may only be transferred to a superior use. (61) Irrigation is defined to be a use superior to industrial use. Water transfers from agricultural to any type of energy 
use is therefore prohibited. Water in Missouri River storage projects is currently plentiful. At some future time, however, this transfer restriction could be significant.

Arizona provides that irrigation districts, agricultural improvement districts and water users associations must approve transfer of water rights within their boundaries or from watersheds supplying their water. (62) The effect of this legislation is possibly mitigated by a State Attorney General's opinion holding that it applies only when the transferred water is to be severed from the 1 and and when the water right is within the jurisdiction of the state land department rather than a court which has retained jurisdiction. Nevertheless the legislation is potentially significant.

In Wyoming, the water right administrator may consider the economic consequences to the community and state which would result from the changed use and whether other sources of water are available for the new use.

The Nevada legislation (49) directing the State Engineer to consider the economic welfare of the state before approving water use changes for power production was mentioned earlier.

Transfer of water from agricultural use to industrial use does not necessarily have to result in less agricultural production. The U.S. Generai Accounting office (GAO) found that many farm lands are over-irrigated. (64) This causes reduced irrigation efficiency, limits crop production, increases farming costs, and contributes to water pollution. Two of the factors cited as contributing to over-irrigating were low water prices and the existing system of water rights. GAO found that when water cost increases, average irrigation efficiency also increases. It also observed that some farmers tend to over-irrigate because they fear losing their existing water quantity rights. In a given season they may also fear that future water supplies will be diminished and they should therefore apply the water while they have it.

The impact on agriculture of future water transfers from irrigation to energy use was investigated as one future scenario in a study for the National Water Assessment. (65) The authors assured sufficient water transfer to allow 
shale oil extraction and to transport and process coal for generation of electricity. They concluded that such transfer would have "little impact on either water prices, consumer food costs, or production patterns," for the remainder of this century.

\subsubsection{Riparian System}

Water rights in riparian jurisdictions may also be sold and transferred. The transferee is subject to the same reasonable use restriction as the transferor. Eastern states with permit procedures do not generally have specific transfer procedures. It is probable that transfers would be approved to new purchasers for the same place and purpose of use, but that proposed transfers to new uses or places of use would be processed as applications for new permits. (45)

In many riparian jurisdictions water cannot be transported for private use on nonriparian land. The question of the extent of riparian lands has been litigated often in Eastern states. The general rule appears to be that riparian land is real property underlying or bordering the watercourse. Riparian land may extend away from the watercourse as long as it is under the same title and is in the same watershed.

There is little information available on the sale of riparian water rights separate from riparian land. (55) The deficiency may exist because water is relatively plentiful in riparian jurisdictions.

\subsubsection{Water Management Organizations}

In the areas of the West where wet/dry cooling is likely to be needed first, i.e., areas where water is fully appropriated and contracted, purchase of water entitlements from some type of water management organization is a likely source of water. In this case, the utility would not be obtaining a water right, because the actual appropriative right will be held by some other entity (e.g., the Water Management Organization or the Bureau of Reclamation). Water management companies exist in a variety of forms, including mutual water companies, mutual ditch companies, conservancy districts, and irrigation districts. Together they deliver the majority of 
the water in the West to the ultimate user. One source reports that in 1964, mutual incorporated ditch companies and water conservancy districts delivered $68 \%$ of the total irrigation water to the user. ${ }^{(66)}$

Transfer of water from water management organizations generally occurs with relatively little difficulty. In mutual water organizations, the purchaser negotiates with shareholders. Purchase of shares entitles him to a certain amount of water which can vary depending upon seasonal flows. Alternatively the utility may be able to simply purchase water entitlement contracts from owners in nonmutual organizations. This type of transfer is common in the Northern Colorado Water Conservancy District, for example. $(27,66)$

Acquisition of water entitlements from water management organizations has several potential advantages for the purchaser. Since the purchaser is obtaining a contract right in water as opposed to a real property right, no legal proceeding before a court or state agency is required. There is somewhat more flexibility regarding the quantity of water purchased and the point of diversion. It is claimed that the return-flow consequences of transfer have little impact. ${ }^{(67)}$ Finally, water management organizations often have storage capacity constructed which could enable a utility to obtain a year-round source of water.

In 1976, a permanent share of water from the Colorado Big Thompson Project in the South Platte River Bas in reportedly cost about $\$ 900$. Each share provides about 0.8 acre-ft per year. ${ }^{(68)}$

\subsection{GROUND WATER}

The extent to which ground water can be used for future cooling is uncertain. Perhaps the chief obstacle to its use is the lack of certainty in future supplies. In many areas where future water pressures will be most severe, ground water is currently being mined, i.e, being withdrawn faster that it is being recharged. The quantity of water available must therefore decrease sometime in the future. 
The quantity of underground water potentially available for use is large. The total amount of ground water in underground storage which is usable with present technology was reported by the National Water Commission to approximate 35 years' annual surface runoff--or about 46 billion acre-ft. Between one-third and one-half of the conterminous U.S. is underlaid by ground water areas capable of yielding $50 \mathrm{gal} / \mathrm{min}$ or more to wells. To date, relatively little ground water has been withdrawn for power plant cooling. In 1970, it was estimated that 170,000 million gallons per day (mgd) were withdrawn in the U.S. for power plant cooling. Of this total, only $1300 \mathrm{mgd}$ represented ground water. (31) of the $1300 \mathrm{mgd}, 850 \mathrm{mgd}$ were estimated to be withdrawn in only three states--California, Minnesota, and Nebraska.

Geographic areas where the water table is declining rapidly include Nebraska, the Texas panhandle, eastern Colorado, and western Kansas. (69) Some geologists estimate that the Texas panhandle will run out of recoverable ground water within 25 years. (69) declined an average of 3.5 feet in 1976. (69) California and Arizona have also experienced overdrafts.

Four ground water law systems exist in the U.S. (70) In much of the East, Midwest, and Texas ground water law is judge-made law, derived from the English common law system. Each landowner is allowed to pump ground water under his land without limit. Many Eastern states do require pumping permits. Two modifications of the common law rule have appeared in the U.S. The reasonable use rule, analogous to the riparian system for surface waters, applies in Arizona. The correlative rights rule is similar to the reasonable use rule and applies in California and other Western states. Literally applied, the correlative rights doctrine allocates to each landowner overlying a ground water basin a share in proportion to his surface ownership.

The prior appropriation system applies in a majority of the western states. Most require permits to withdraw water. States having appropriation permit systems include Alaska, Kansas, Nevada, New Mexico, North Dakota, Oklahoma, Oregon, South Dakota, Utah, Washington, and Wyoming. Arizona, California, and Montana apply the appropriation system to particular areas. 
The extent to which ground water mining is regulated varies from state to state. In California, the State Supreme Court established a rule requiring prorata cutbacks in pumping when an aquifer is overdrawn. (71) The Orange County Water District in California has a comprehensive ground water management system which requires those pumping water to pay an assessment if they pump water in excess of what the District considers reasonable for the year. (56) Some western states, including Oregon, Wyoming, Nevada, Arizona, and New Mexico utilize a quota system which may exclude new pumpers from an aquifer. South Dakota and Idaho have statutes which prohibit the withdrawal of ground water in quantities which exceed natural recharge. Although ground water mining is detrimental to a utility by making future supplies uncertain, it could be partly advantageous because as the water table drops, agricultural users will likely abandon their rights when pumping costs exceed the value of the water to them.

In seeking to acquire ground water, a utility can purchase an existing pumping operation and use the water on the site or it can purchase water and transport it to a new location. Under the common law rule, the water can be transported away from the pumping point. Under the other ground water law systems, transfer outside the basin in which it is found may not be accepted if other users within the basin are injured. (72)

The G.E. (1) and HEDL ${ }^{(33)}$ studies considered the use of ground water in making their wet/dry cooling projections. It is difficult to generalize about how widely ground water will be used in the future because the variables affecting its use are so site specific. Use for particular plants will rikely depend on whether an assured supply can be obtained and whether the locations with ground water available are consistent with other plant siting criteria. 

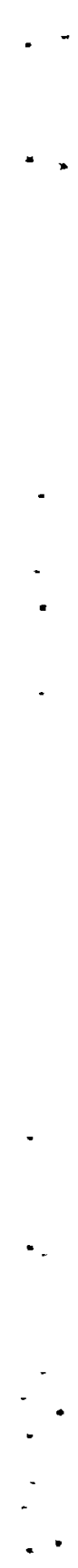


\subsection{LEGAL UNCERTAINTIES COMPLICATING THE ACQUISITION OF WATER}

A variety of legal uncertainties exist which can complicate the acquisition of water. Several sources of uncertainty, such as incomplete and inaccurate water rights records, were identified in the preceding section. Three other elements of uncertainty are discussed in this section: Indian water rights, other Federal reserved rights, and preservation of instream water. This list is clearly not exhaustive.

\subsection{INDIAN WATER RIGHTS}

Indian water rights may be the most significant element of legal uncertainty facing the utility seeking water for cooling. Indian rights derive from the implied reservation doctrine which was first applied by the Supreme Court in the Winters case ${ }^{(73)}$ to an Indian reservation in Montana in 1908. The doctrine was later applied to other Federal reserved lands in Arizona v. California. (74)

The implied reservation doctrine can be stated in the following way. When the public lands, e.g., national forests and parks, and Indian reservations were set aside by the Congress for special use, there was reserved by implication for each conclave "enough of the then unappropriated water appurtenant to the lands reserved to effectuate whatever purpose the reserved lands were set aside to serve, and this constitutes a water right with a priority of the date the lands were reserved." (75) The doctrine has raised a host of unanswered questions among which are: How much water is reserved? Must the water be used on the reservation? Can the water be sold? What purposes can the water be used for? Does the purpose have to have been foreseeable when the 1 and was reserved? These questions have only been partially answered, if at all.

In Arizona v. California, the Supreme Court determined that five Indian reservations in Arizona, Califonia, and Nevada were entitled to water priorities dating back to 1864 in the amount of about 1 million acre-ft annually. This represents about $15 \%$ of the water supply in the 
lower Colorado River Basin. This water is available for development, and could potentially displace existing water uses. Alternatively this water and other water reserved for Indian use may very well be available for purchase by utilities. No legislation specifically prohibits the sale of Indian water rights. Without the capital to fully exploit their water right, Indian tribes may be willing in some instances to sell their water.

The water allocation in Arizona v. California was based on irrigation requirements. For Indian reservations in areas without irrigation potential, the allocation may be based on other criteria, perhaps even energy development. (77) This possibility complicates further the question of how much water is within the scope of the reserved right.

\subsection{OTHER FEDERAL RESERVED RIGHTS}

Implied water reservations for public lands stem from the decision in Arizona v. California. The amount of water potentially affected by Federal reserved rights is large indeed. In the eleven conterminous western states, $59 \%$ of the total water yield flows from National Forest and National Park reservations. (78) Except for Indian water rights, however, the quantity of water involving Federal rights adjudicated under the reservation doctrine has been relatively small. As of 1972, Professor Charles Corker of the University of Washington Law School was able to find only one case where a water user exercising a valid state water right had been forced to surrender it to Forest Service use under the reservation doctrine. (75) Professor Corker also points out that the doctrine is not really needed by the Federal Government. It could obtain all the water it requires through exercise of eminent domain. Given the vast sums that have been spent in developing western water, the amount of money necessary to condemn needed water does not seem to be a compelling reason for the Federal government to rely on reserved rights rather than eminent domain.

A recent Supreme Court case, Cappaert v. United States, (79) has extended the Federal reserved rights doctrine to ground water. The suit was brought by the U.S. to preserve the water level in Devil's Hole, a limestone cavern 
in Nevada, which is a detached component of Death Valley National Monument. The defendants pumped ground water outside the monument for irrigation. The pumping, however, lowered the water level in the cavern and endangered a unique species of desert fish called pupfish. The Supreme Court affirmed the lower court decision which permanently enjoined pumping that would lower the water level sufficiently to endanger the fish. The most significant aspect of the case may be its potential precedent value in establishing ground water rights for Indian reservations. Ground water pumping often requires lower capital expenditure than surface water diversion systems. Indians with ground water access may therefore be more inclined to initiate irrigation, to the possible detriment of other ground water users.

\subsection{PRESERVATION OF INSTREAM WATER}

In recent years there has been a trend toward preservation of instream water for aesthetic, recreation, and fish and wildlife purposes. The trend has occurred at both the Federal and state level.

The principal Federal involvement originated with passage of the National Wild and Scenic Rivers Act of 1968. (80) Section 7 (A) of the Act provides that no Federal agency may assist by loan, grant, license, or otherwise in the construction of a water resources project which would have a direct and adverse effect on the natural river values as determined by the management agency. For practical purposes, the Act probably precludes the consumptive use of water for power plant cooling from stretches of rivers within the Wild and Scenic Rivers System. Water projects above or below the protected area may be acceptable if the administering U.S. agency determines that the project does not have an unreasonable impact. The rivers currently in the Wild and Scenic Rivers System are shown in Table 8.

Most western states have taken legislative and/or administrative steps to preserve instream water. (81) The power of the state to accomplish the preservations has usually been upheld, and in some cases even extended, by the state courts. 
TABLE 8. Components of the National Wild and Scenic Rivers System

\begin{tabular}{|c|c|c|c|c|c|c|c|}
\hline \multirow{2}{*}{ River } & \multirow{2}{*}{ Location } & \multirow{2}{*}{$\begin{array}{c}\text { Administering } \\
\text { agency }\end{array}$} & \multicolumn{3}{|c|}{ Miles by classification } & \multirow{2}{*}{$\begin{array}{l}\text { Total } \\
\text { miles }\end{array}$} & \multirow{2}{*}{ Status/Public Law } \\
\hline & & & Wild & Scenic & Recreational & & \\
\hline $\begin{array}{l}\text { Middle Fork Clearwater } \\
\text { Eleven Point } \\
\text { Feather } \\
\text { Rio Grande }\end{array}$ & $\begin{array}{l}\text { Idaho } \\
\text { Missouri } \\
\text { California } \\
\text { New Mexico }\end{array}$ & $\begin{array}{l}\text { FS } \\
\text { FS } \\
\text { FS } \\
\text { BLM/FS } \\
(B L M)\end{array}$ & $\begin{aligned} 54 \\
-32.9 \\
51.75 \\
(43.90)\end{aligned}$ & $\begin{array}{r} \\
\quad 44.4 \\
-\quad 9.7 \\
=\end{array}$ & $\begin{array}{c}131 \\
-50.4 \\
1 \\
(0.25)\end{array}$ & $\begin{array}{l}185 \\
44.4 \\
93 \\
52.75 \\
(44.15)\end{array}$ & $\begin{array}{l}\text { P.L. 90-542, } 10 / 2 / 68 \\
\text { P.L. 90-542, } 10 / 2 / 68 \\
\text { P.L. 90-542, } 10 / 2 / 68 \\
\text { P.L. 90-542, } 10 / 2 / 68\end{array}$ \\
\hline Rogue & Oregon & $\begin{array}{l}\text { BLM/FS } \\
(B L M) \\
(F S)\end{array}$ & $\begin{array}{l}33.85) \\
30 \\
(20)\end{array}$ & & $\begin{array}{l}44^{2} \\
(27)\end{array}$ & $\begin{array}{l}(8.60) \\
84.5 \\
(47)^{5}\end{array}$ & $\begin{array}{l}\text { P.L. 92-542, 10/2/68 } \\
\text { P.L. 92-542, } 10 / 2 / 68\end{array}$ \\
\hline $\begin{array}{l}\text { St. Croix } \\
\text { Middle Fork Salmon } \\
\text { Wolf } \\
\text { Allagash }\end{array}$ & $\begin{array}{l}\text { Minnesota/Wisconsin } \\
\text { Idaho } \\
\text { Wisconsin } \\
\text { Maine }\end{array}$ & $\begin{array}{l}\text { NPS/FS } \\
\text { FS } \\
\text { NPS } \\
\text { State }\end{array}$ & $\begin{array}{l}-13) \\
-103 \\
-\quad 95\end{array}$ & $\begin{array}{l}181 \\
-25 \\
-\end{array}$ & $\begin{aligned} &(17) \\
& 19 \\
& 1 \\
&-\end{aligned}$ & $\begin{array}{l}(37.5) \\
200 \\
104 \\
25 \\
95\end{array}$ & $\begin{array}{l}\text { P.L. 90-542, } 10 / 2 / 68 \\
\text { P.L. 90-542, } 10 / 2 / 68 \\
\text { P.L. 90-542, } 10 / 2 / 68 \\
\text { Secretarial designation } \\
7 / 19 / 70\end{array}$ \\
\hline Lower St. Croix & Minnesota/Wisconsin & $\begin{array}{l}\text { NPS } \\
\text { Minnesota/ } \\
\text { Wisconsin }\end{array}$ & $=$ & -12 & $\begin{array}{l}15 \\
25\end{array}$ & 27 & $\begin{array}{l}\text { P.L. 92-560, } 10 / 25 / 72, \\
\text { Secretarial designation } \\
6 / 17 / 76\end{array}$ \\
\hline Chattooga & $\begin{array}{l}\text { North Carolina/South } \\
\text { Carolina/Georaia }\end{array}$ & FS & 39.8 & 2.5 & 14.6 & 56.9 & P.L. $93-279,5 / 10 / 74$ \\
\hline Little Miami & Ohio & State & - & 18 & 48 & 66 & $\begin{array}{l}\text { Secretarial designation } \\
8 / 20 / 73\end{array}$ \\
\hline l.ittle Beaver & Ohio & State & - & 33 & - & 33 & Secretarial designation \\
\hline $\begin{array}{l}\text { Snake } \\
\text { Rapid } \\
\text { New }\end{array}$ & $\begin{array}{l}\text { Idaho/Oregon } \\
\text { idahoo } \\
\text { North Carolina }\end{array}$ & $\begin{array}{l}\text { FS } \\
\text { FS } \\
\text { State }\end{array}$ & $-^{32.5}$ & $\begin{array}{r}34.4 \\
-\quad 26.5\end{array}$ & $\begin{array}{l}- \\
\overline{-}\end{array}$ & $\begin{array}{l}66.9 \\
24 \\
26.5\end{array}$ & $\begin{array}{l}\text { P.L. } 94-199,12 / 31 / 75 \\
\text { P.L. } 94-199 ; 12 / 31 / 75 \\
\text { Secretarial designation } \\
4 / 13 / 76\end{array}$ \\
\hline $\begin{array}{l}\text { Missouri } \\
\text { Flathead } \\
\text { Obed }\end{array}$ & $\begin{array}{l}\text { Montana } \\
\text { Montana } \\
\text { Tennessee } \\
\end{array}$ & $\begin{array}{l}\text { BLM } \\
\text { NPS/FS } \\
\text { NPS/State }\end{array}$ & $\begin{array}{r}72 \\
97.9 \\
45.2 \\
\end{array}$ & $\begin{array}{l}18 \\
-40.7 \\
-\end{array}$ & $\begin{array}{r}59 \\
80.4 \\
-\quad \\
\end{array}$ & $\begin{array}{r}149 \\
219 \\
45.2 \\
\end{array}$ & $\begin{array}{l}\text { P.L. } 94-486,10 / 12 / 76 \\
\text { P.L. } 94485,10 / 12 / 76 \\
\text { P.L. } 94-48 \overline{0}, 10 / 12 / 76 \\
\end{array}$ \\
\hline Total & & & 681.05 & 452.7 & 448.4 & $1,655.15$ & \\
\hline
\end{tabular}

Source: U.S. Department of the Interior, Bureau of Outdoor Recreation, "River Mileage Classifications for Components of the National Wild and Scenic Rivers System," 1977. 


\section{ACKNOWLEDGMENTS}

This report contains an account of the work originally sponsored by the Division of Nuclear Research and Applications of ERDA under the Dry Cooling Tower Project at Battelle, Pacific Northwest Laboratory (PNL). This revision and updating was sponsored by the Department of Energy, Environmental Control Division under the direction of Charles Grua through the PNL Dry/wet Cooling Tower Project.

The following personnel at PNL made valuable critiques of this work: R. T. Allemann, J. W. Currie, J. C. King, and B. M. Johnson, Manager of the PNL Dry Cooling Tower Project. A. Currie edited the final draft. 

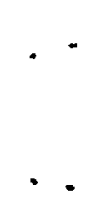


\section{REFERENCES}

1. General Electric Company, San Jose, CA, Future Needs for Dry or Peak Shaved Dry/Wet Cooling and Significance to Nuclear Power Plants, EPRI NP-150, prepared for the Electric Power Research Institute, Palo Alto, CA, February 1976.

2. U.S. Energy Research and Development Administration, A National Plan for Energy Research Development and Demonstration, ER $\overline{D A-48, ~ V o l . ~ 1, ~}$ June 1975.

3. Espey, Huston, and Associates, Inc., Consumptive Use Implications of the Proposed EPA Effluent Guidelines for Steam-Electric Power Generation, May 31, 1974, included in Edison Electric Institute Utility Water Act Group (UWAG) comments on EPA's Proposed $\$ 304$ Guidelines and $\S 306$ Standards of Performance for Steam Electric Power Plants, June 26, 1974.

4. See, Future Developments in Waste Heat Utilization, Oregon State University Engineering Experiment Station Circular No. 49, September 1975.

Atomic Energy of Canada Limited, Low-Grade Heat: A Resource in Cold Climates, Chalk River Nuclear Laboratories, Chalk River, Ontario, January 1976 .

5. R. J. Huston, "An Overview of Water Requirements for Electric Power Generation," in E. F. Gloyna, H. H. Woodson and H. R. Drew, editors, Water Management by the Electric Power Industry, University of Texas at Austin Center for Research in Water Resources, 1975.

6. M. C. Hu, et a1., Water Consumption and Costs for Various Steam Electric Power Plant Cooling Systems, EPA-600/7-78-157, August 1978.

7. FWPCA, Section 101 (a) (11), 33 U.S.C., \$1251 (a) (1).

8. FWPCA, Section 502 (6), 33 U.S.C., §1362 (6).

9. FWPCA, Section 316, 33 U.S.C., §1326.

10. 40 CFR $\$ 423.11$ (d), $423.13(1),(m)$.

11. 40 CFR $\S 423.15$ (1), 423.25 (1).

12. 545 F.2d 1351, 9 ERC 1033 (1976).

13. 40 CFR $\S 423.13$ (1) (3), §423.15 (1) (2).

14. 40 CFR $\S 423.15$ (1), 40 CFR, $\S 423$ (1).

15. 41 Federal Register 12694, March 26, 1976.

16. Business Week, Ju1y 3, 1978, p. 79. 
17. M. C. Hu, et al., United Engineers and Constructors, Inc., Philadelphia, PA, Engineering and Economic Evaluation of Wet/Dry Cooling Towers for Water Conservation, LE\&C-ERDA-761130, p. 5-8, November 1976.

18. M. Cheng, T. E. Croley, V. C. Patel, Iowa Institute of Hydraulic Research, Analys is of Different Types of Dry-Wet Cooling Towers, National Technical Information Service (NTIS) No. PB-261-315, p. 157, July 1976.

19. H. Gold, et al., Water Purification Associates, Water Reguirements for Steam-Electric Power Generation and Synthetic Fuel Plants in the Western U.S., EPA-600/7-77-037, PB-268 062, Apri1 1977.

20. Northern Great Plains Resources Program, Effects of Coal Development in the Northern Great Plains, Denver Federal Center, Denver, C0, April 1975.

21. K. Ladd, "City Wastewater Re-Used for Power Plant Cooling and Boiler Make-Up," in Ref. 5.

See also, "Treated Sewage for Power Plant Makeup Water," 76 Power Engineering 40, November 1972.

22. Los A1amos Scientific Laboratory, Water Requirements for Future Energy Development in the West: State Perspectives, LA-6688-MS, August 1977.

23. U.S. Nuclear Regulatory Commission, Final Environmental Statement for Palo Verde Nuclear Generating Station, Units 1, 2, and 3, NUREG-75/078, p. 9-15, September 1975.

24. Johin R. Teerink, Bookman-Edmonston Engineering, Inc., The Impact of Power Plant Siting on California's Water Resources, prepared for the Association of California Water Agencies, Sacramento, CA, p. 32, July 1976.

25. California Dept. of Water Resources, University of California Seawater Conversion Laboratory, Agricultural Waste Water for Power Plant Cooling Development and Testing of Treatment Processes, June 1978.

26. Kaiser Engineers, Economic Study of the Use of Agricultural Waste Water for Power Plant Cooling Water Makeup, prepared for the Electric Power Research Institute, January 1977.

27. Irrigation districts often construct storage capacity in order to increase the volume of water available for summer irrigation. See R. L. Dewsnup, "Assembling Water Rights for a New Use: Needed Reforms in the Law," 17 Rocky Mountain Mineral Law Institute 613, Matthew Bender \& Co., New York, NY, 1972.

28. See Victor E. Gleason, "Water Projects Go Underground", 5 Ecology Law Quarterly 625, 1976.

29. Robert A. Young and S. Lee Gray, Economic Value of Water: Concepts and Empirical Estimates, NTIS, No. PB-210-356, p. 308, March 1972. 
30. Maurice M. Kelso, et a1., Water Supplies and Economic Growth in an Arid Environment, an Arizona Case Study, The University of Arizona Press, 1973. Cited in Reference 21.

31. C. R. Murray and E. B. Reeves, Estimated Use of Water in the U.S. in 1975, U.S. Geological Survey Circular 765, 1977.

32. U.S. Department of the Interior, Westwide Study Report on Critical Water Problems Facing the Eleven Western States, p. 75, April 1975.

33. D. E. Peterson, J. C. Sonnichsen, Hanford Engineering Development Laboratory, Richland, WA, Assessment of Requirements for Dry Towers, HEDL-TME 76-82, prepared for the U.S. Energy Research and Development Administration, September 1976.

34. The water situation in Pennsylvania is discussed in R. T. Weston and J. R. Gray, "Legal Control of Consumptive Water Use in Pennsylvania Power Plants," 80 Dickinson Law Review 354, Spring 1976.

35. Water for Energy Management Team, U.S. Department of the Interior, Report on Water for Energy in the Upper Colorado River Basin, July 1974.

36. Allen V. Kneese and F. Lee Brown, "Water Demands for Energy Development," 8 Natural Resources Lawyer 311, 1975.

37. Water for Energy Management Team, U.S. Department of the Interior, Report on Water for Energy in the Northern Great Plains Area with Emphasis on the Yellowstone River Basin, p. VII-1, January 1975.

38. Water Resources Division, Montana Department of Natural Resources and Conservation, The Future of the Yellowstone River ..... ?, January 1977.

39. Ref. 20, p. 80 .

40. California State Water Resources Control Board, Sacramento, CA, "Water Quality Control Policy on the Use and Disposal of Inland Waters Used for Power Plant Cooling," June 19, 1975.

41. California Energy Resources Conservation and Development Administration, Electricity Forecasting and Planning Report, p. VI-31, September 1976.

42. Ibid, p. VI-36.

43. Ibid, p. VI-38.

44. Ref. 24, op cit, p. 31 .

45. Richard L. Dewsnup and Dallin W. Jensen, editors, A Summary - Digest of State Water Laws, prepared for the National Water Commission, U.S. Government Printing Office, 1973. 
46. Alaska Statutes $\$ 46.16 .080$.

47. California Water Code §1253-1258.

48. Oregon Revised Statutes $\$ 537.170$.

49. Nevada Revised Statutes $\$ 533.370$.

50. Session Laws, Chapter 275 (1975).

51. Montana Statutes 89-867(2).

52. Richard L. Dewsnup, "Problems Under State Water Laws: Initiation of New Rights," 8 Natura1 Resources Lawyer 347 (1975).

53. Environmental Defense Fund, Inc. v. Morton, 420 F. Supp 1037 (1976). See also, George W. Pring and Laurence Edelman, "Reclamation Law Constraints on Energy/Industrial Uses of Western Water, " 8 Natural Resources Lawyer 297 (1975).

54. Frank J. Trelease, Water Law: Resource Use and Environmental Protection, West Publishing Co., St. Paul, MN, p. 735, 1974.

55. Charles Meyers and Richard A. Posner, Market Transfers of Water Rights: Toward an Improved Market in Water Resources, NTIS No. PB-202-620, July 1971

56. National Water Commission, Water Policies for the Future, U.S. Government Printing Office, June 1973.

57. Frank J. Trelease, "Changes and Transfers of Water Rights," 13 Rocky Mountain Mineral Law Institute 507, Matthew Bender \& Co., 1967.

58. Ref. 54, op cit., p. 215.

59. California Farm Bureau Federation, Farm Bureau Policies 1977, Sacramento, CA.

60. Montana Revised Codes Annotated §89-892 (3).

61. North Dakota Century Code 61-04-15.1.

62. Arizona Revised Statutes 45-172.

63. Wyoming Statutes $\$ 41-4.1$.

64. U.S. General Accounting Office, "Better Federal Coordination Needed to Promote More Efficient Farm Irrigation," B-114885, June 22, 1976. 
65. A. D. Meister, et a1., Center for Agricultural and Rural Development, Iowa State University, U.S. Agricultural Production in Relation to Alternative Water, Environmenta 1, and Export Policies, June 1976.

66. L. M. Hartman and Don Seastone, Water Transfers: Economic Efficiency and Alternative Institutions, Johns Hopkins Press, Baltimore, MD, p. 35, 1970.

67. Ref. 55, op cit, p. 35 .

68. J. C. Kellogg, Technology Assessment for New Water Development Projects, PB-259, 276, August 1976.

69. The Wal1 Street Journal, May $31,1977$. p. 1, col. 8.

70. Robert Emmet Clark, "Ground Water Law: Problem Areas," 8 Natural Resources Lawyer 377, 1975.

71. Pasadena v. A1hambra, 207 P.2d 17 (1949).

72. See 78 American Jurisprudence Second Edition, p. 610.

73. Winters v. United States, 207 U.S. 564 (1908).

74. Arizona v. California, 373 U.S. 546 (1963).

75. Charles E. Corker, "Federal-State Relations in Water Rights Adjudication and Administration," 17 Rocky Mountain Mineral Law Institute 582, Matthew Bender \& Co., 1972.

76. Monroe E. Price and Gary D. Weathorford, "Indian Water Rights in Theory and Practice: Navajo Experience in the Colorado River Basin," 40 Law and Contemporary Problems 104, Duke University School of Law, Winter 1976.

77. Frank J. Trelease, Federal-State Relations in the Law of Water Rights, NTIS No. PB-203-600, p. 162-166, 1971.

78. Public Land Law Review Commission, One Third of the Nation's Land 141, U.S. Government Printing Office, 1970.

79. Cappaert v. United States, 96 S.Ct. 2062 (1976).

80. 16 U.S.C. $\S 1271-87$.

81. A. Dan Tarlock, "Recent Developments in the Recognition of Instream Uses in Western Water Law," 1975 Utah Law Review 871, Winter 1975; and, "New" Public Western Water Rights: Appropriation for Instream Flow Maintenance," presented at Water Acquisition for Mineral Development Institute, sponsored by the Rocky Mountain Mineral Law Foundation, March 17, 1978. 


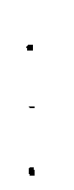




\section{DISTRIBUTION}

No. of

Copies

$\underline{\text { OFFSITE }}$

U.S. Department of Energy

A. A. Churm

Chicago Patent Group

9800 South Cass Avenue

Argonne, IL 60439

U.S. Department of Energy

Office of Assistant General

Counsel for Patents

Washington, DC 20545

27 DOE Technical Information Center

10 U.S. Department of Energy

I. Helms

Advanced Concepts Evaluation Branch - G-434

Division of Advanced Systems and Materials

Washington, DC 20545

U.S. Department of Energy

W. F. Savage

Chief, Advanced Concepts Evaluation Branch

Division of Advanced Systems and Materials

Washington, DC 20545

U.S. Department of Energy

D. C. Bauer

Director, Division of Advanced

Systems and Materials

Washington, DC 20545

U.S. Department of Energy

R. B. Morrow

Special Projects Branch

Division of Advanced Systems and Materials

Washington, DC 20545
No. of

Copies

U.S. Department of Energy

N. Gerstein

Chief, Special Projects Branch

Division of Advanced Systems and Materials

Washington, DC 20545

U.S. Department of Energy

W. E. Mott

Director, Energy Control Technology

Division of Biomedical and

Environmental Research

Washington, DC 20545

U.S. Department of Energy

G. A. Newby

Assistant Director, Office of Technical Development

Division of Advanced Systems and Materials

Washington, DC 20545

Allied Chemical Company

B. R. Dickey

550 2nd Street

Idaho Falls, ID 83401

Allis-Chalmers Power Systems, Inc.

J. S. Joyce

1135 South 70th Street

West Allis, WI 53214

Aluminum Company of America

E. T. Wanderer

Alcoa Technical Center

Alcoa Center, PA 15069

American Electric Power

H. J. Janzon

2 Broadway

New York, NY 10004

American Electric Power

Service Corporation

C. Swens on

2 Broadway

New York, NY 10004 
No. of

Copies

Aqua-Chem

R. M. Ahlgren

P. 0. Box 421

Mi lwaukee, WI 53201

Arizona Public Service Co.

W. E. Campbe 11

P. 0. Box 21666

Phoenix, AZ 85036

Arizona Public Service Co.

$T$. Woods

$2121 \mathrm{~W}$. Cheryl Drive

Phoenix, AZ 85021

Babcock \& Wilcox

M. W. Peterson

Fossil Power Division

20 South Van Buren

Barberton, $\mathrm{OH} 44203$

Baltimore Aircoil Co., Inc.

E. Schinner

P.0. Box 7322

Baltimore, MD 21227

Baltimore Gas \& Electric Co.

G. C. Creel

Gas \& Electric Building

Baltimore, MD 21203

Battelle-Geneva

J. P. Budliger

7 Route De Drizi

1227 Geneva, SWITZERLAND

Bechtel Corporation

$P$. Leung

P.0. Box 60860

Terminal Annex

Los Angeles, CA 90060

Bechtel Corporation

G. R. Reti

P.0. Box 3965

San Francisco, CA 94119
No. of

Copies

R. W. Beck and Associates

J. P. Rossie

400 Prudential Plaza

Denver, CO 80202

Betz Environmental Engineers

J. Soost

$9317 \mathrm{~J}$, Highway 99

vancouver, WA 98665

Black, Crow and Eidsness, Inc.

C. G. Thompson

807 South McDonough

Montgomery, AL 35104

Black Hills Power and Light Company

B. Westre

P.0. Box 1400

Rapid City, SD 57701

Boeing Aerospace Division

D. Gilbert (M.S. 2R00)

P.0. Box 3999

Seattle, WA 98124

Bonneville Power Administration

E. H. Hall

1002 N.E. Holladay Street

Box 3621

Portland, OR 97208

Burns and Roe, Inc.

700 Kinder Kamack Rd.

Oradel, NY 07649

California Energy Commission

c. Webb

1111 Howe Avenue

Sacramento, CA 95825

California State Energy Resources Conservation and Development Commission

L. E. Stamets

1111 Howe Avenue

Sacramento, CA 95825 
No. of

Copies

Carolina Power \& Light Co. J. Sell

336 Fayettesville Street

Raleigh, NC 27602

Catalytic Construction Corp.

J. Morse

P.0. Box 11402

Charlotte, NC 28029

Ceramic Cooling Tower Co.

P. A. Frohwerk

P. 0. Box 425

Fort Worth, TX 76101

Chicago Bridge and Iron Company

C. T. Bouchard

Route 59

Plainfield, IL 60544

Combustion Engineering Lummus Engineering Company

R. J. Croke

1515 Broad St

Bloomingfield, NJ 07003

Columbus and Southern Ohio

Electric Co.

L. W. Meridith

General Manager, Generation

Department

215 North Front Street

Columbus, $\mathrm{OH} 43215$

Combustion Engineering

H. H. Osborn

Air Preheater Company

Wellsville, NY 14895

Commonwealth Edison

R. H. Holyoak

One First Plaza

P.0. Box 767

Chicago, IL 60690

Consolidated Edison Co. of New York, Inc.

W. A. Messner

4 Irving Place

New York, NY 10003
No. of

Copies

Consolidated Edison Co. of New York, Inc.

C. L. Newman

4 Irving Place

New York, NY 10003

Corne 11 University

F. K. Moore

Ithaca, NY 14850

Curtiss-Wright Corporation

R. J. Haberski

One Passaic Street

Wood Ridge; NJ 07075

Dames \& Moore

L. Craton

Suite 1000

1100 Glendon Avenue

Los Angeles, CA 90024

Dames \& Moore

P. Gottlieb

Suite 1000

1100 Glendon Avenue

Los Angeles, CA 90024

Delmarva Power \& Light

F. Cook

800 King Street

Wilmington, DE 19801

Dow Chemical Company

E. Wagener

2800 Mitchell Drive

Walnut Creek, CA 94598

Duke Power Company

S. K. Blackley

P. 0. Box 2178

Charlotte, NC 28201

Duquesne Light Co.

J. Latshaw

435 6th Avenue

Pittsburgh, PA 15219

Dynatech Company

E. Guyer

99 Erie Street

Cambridge, MA 02139 
No. of

Copies

Ecodyne

J. Slotnik

607 First Street, S.W.

Massilion, $\mathrm{OH} 44646$

Ecodyne Cooling Products Co.

J. K. Swindt

P.0. Box 1267

Santa Rosa, CA 95403

Ecodyne Cooling Products

K. D. Whitehead

P.0. Box 1267

Santa Rosa, CA 95403

Electric Power Research Institute

J. Maulbetsch

$3412 \mathrm{Hi} 11$ view Avenue

P. 0. Box 10412

Palo Alto, CA 94304

Empire State Electric Energy Research Corp.

L. Geller

1271 Avenue of the Americas

New York, NY 10020

Environmental Protection Agency

T. G. Brna (MD-61)

IERL/RTP

Research Triangle Park, NC 27711

Environmental Protection Agency

A. Galley (WH-552)

401 M. Street SW

Washington, DC 20460

Environmental Protection Agency

M. Maxwe11 (MD-61)

IERL/RTP

Research Triangle Park, NC 27711
No. of

Copies

Environmental Protection Agency

F. H. Rainwater

Pacific Northwest Water Laboratory

200 S.W. 35th Street

Corvallis, OR 97330

Environmental Protection Agency

F. A. Roberts

200 S.W. 35th Street

Corvallis, OR 97330

Environmental Sciences and Services

W. G. Hoydysh

150 East 73rd Street

New York, NY 10021

Environmental Systems Corporation K. Wilber

P. 0. Box 2525

Knoxville, TN 37901

ERG Incorporated

G. M. Benson

Lowel1 57th Street

0akland, CA 94608

Exxon Research Center

J. G. Stevens

B 1dg. 1, Rm. 2048

P.0. Box 8

Linden, NJ 07036

Federal Power Commission

E. Sligh

825 N. Capitol Street

Washington, DC 20426

Florida Power \& Light Co.

$C$. Henderson

9250 W. Flagler Street

Miami, FL 33174 
No. of

Copies

Foster Wheeler Energy Co.

E. L. Damon

110 S. Orange Avenue

Livingston, NJ 07039

Franklin Institute

A. M. Rubin

Twentieth \& Parkway

Philadelphia, PA 19103

Frick Company

J. Bibcoff

15302 E1 Mar Lane

Kerman, CA 93630

GEA Airexchangers, Inc.

B. Davis

P.0. Box 1377

Thomasville, GA 31792

General Atomic Company

A. C. Eulberg

P.0. Box 81608

San Diego, CA 92138

General Electric Co.

E. H. Miller

Large Steam Turbine Division

300 Nott Street

Schenectady, NY 12301

General Motors Corp.

R. K. Shah

Harrison Radiator Division

Lockport, NY 14094

Georgia Power Co.

T. E. Byerley

P. 0. Box 4545

Atlanta, GA 30302

Gilbert Associates, Inc.

J. F. Sebald

525 Lancaster Avenue

Reading, PA 19603

Heat Transfer Research Inc.

J. E. Taborek

1000 S. Fremont Avenue

Alhambra, CA 91802
No. of

Copies

Hudson Products

M. W. Larinoff

6855 Horwin Drive

Houston, TX 77036

Huds on Products

E. C. Smith

6855 Horwin Drive

P.0. Box 36100

Houston, TX 77036

H2M Corporation

H. D. Freudentha 1

500 Broad Hol low Road

Melville, NY 11746

Ingersol1-Rand

W. R. Scott, Jr.

Phillipsburg, NJ 08865

Ital impianti-Societa

Italiana Impianti p.a.

C. Rocco

Piazza, Piccapietra 9

18121 Genoe, ITALY

Los Angeles Department of Water and Power

J. L. Mulloy

111 N. Hope Street

Los Angeles, CA 90012

Louisiana Power \& Light Co.

D. L. Aswell

142 Delaronde Street

New Orleans, LA 70174

The Charles T. Main Co.

E. S. Miliaras

Southeast Tower

Prudential Center

Boston, MA 02199

Marley

C. A. Baird

12 S. 12th Street

Philadelphia, PA 19107 
No. of Copies

Marley

J. D. Holmberg

5800 Fox Ridge Drive

Mission, KS 66202

Marley

R. Landon

5800 Fox Ridge Drive

Mission, KS 66202

Martin Marietta Laboratories

L. Bongers

1450 South Rolling Road

Baltimore, MD 21227

Massachusetts Institute of Technology

L. R. Glicksman

77 Massachusetts Avenue

Cambridge, MA 02139

Massachusetts Institute of Technology

M. W. Golay

77 Massachusetts Avenue

Cambridge, MA 02139

Massachusetts Institute of Technology

R. Harleman

Department of Civil Engineering

77. Massachusetts Avenue

Cambridge, MA 02139

McDonne 11 Douglas Astronautics Co.

W. H. P. Drummond

5301 Balsa Avenue

Huntington Beach, CA 92647

McDonnel1 Douglas

Astronautics Co.

S. D'Hare

5301 Balsa Avenue

Huntington Beach, CA 92647
No. of

Copies

Minnesota Power Cooperative, Inc. L. A. Hillier

Box 1318

Grand Forks, ND 58201

Montana Power Co.

R. Hofacher

40 E. Broadway

Butte, MT 59701

Niagara Blower

W. Kals

405 Lexington Avenue

New York, NY 10017

Northeast Utilities

R. H. Meyer

P.0. Box 270

Hartford, CT 06101

Northern States Power Co.

R. Stansfield

414 Nicollet Mall

Minneapolis, MN 55401

N.U.S. Corporation

S. Lefton

2 Palo Alto Square (Suite 624)

Palo A1to, CA 94304

Oak Ridge National Laboratory

J. W. Michel

OTEC Heat Exchange Project Activity

Box Y

Oak Ridge, TN 37830

Orange \& Rockland Utilities, Inc. R. H. Metzger

Environmental Services Manager

75 West Route 59

Spring Valley, NJ 10977 
No. of

Copies

Oregon State University

L. P. Davis

Department of Mechanical

Engineering

Corvallis, OR 97330

Oregon State University

C. E. Wicks

Department of Chemical

Engineering

Corvalis, OR 97330

Oregon State University

J. G. Knudson

Engineering Experiment

Station

Corvallis, OR 97330

Pacific Gas \& Electric

A. A. Ariey

77 Beale Street

San Francisco, CA 94106

Pacific Gas \& Electric

F. F. Mautz

77 Beale Street

San Francisco, CA 94.106

Pacific Power \& Light Co.

W. C. Bruaer

Public Service Bldg.

Portland, OR 97204

Pennsylvania Power \& Light

W. Dussinger

2 North Ninth Street

Allentown, PA 18101

Pennsylvania Power \& Light

D. G. Pfeiffer

2 North Ninth Street

Allentown, PA 18101

PFR Engineering Systems, Inc.

T. Rozenmann, President

Suite 832

4676 Admiralty Way

Marina del Rey, CA 90291
No. of

Copies

Philadelphia Electric Co.

J. Allen

2301 Market Street

Philadelphia, PA 19101

Phi ladelphia Electric Co.

S. J. Kowalski

2301 Market Street, NZ-1

Philadelphia, PA 19101

Philadelphia Electric Co. J. B. Machel

2301 Market Street, NZ-1

Philadelphia, PA 19101

Philadelphia Electric Co.

D. Marano

2301 Market Street, NZ-1

Philadelphia, PA 19101

Prof. Ing. Carlo Roma

Piazza delle Muse 8

Rome, ITALY

Pickard Low \& Garrick

L. Rust

1200 18th St. NW

Suite 612

Washington, DC 20036

Power Generation Cooling

Sys tems

G. L. Henderson

4714-52nd Street S.

Seattle, Wa 98118

Public Service of Colorado

R. F. Walker

5900 E. 39th Avenue

Denver, CO 80207

Public Service Company of Indiana

S. W. Shields

$V$. P. Engineering

100 E. Main Street

Plainfield, IN 46168 
No. of

Copies

Public Service Company of New Mexico

C. D. Bedford

P.0. Box 2267

Albuquerque, NM 87103

Public Service Company of New Mexico

J. D. Maddox Corporate Planning Dept.

Albuquerque, NM 87103

Quirk, Lawler and Mattusky, Eng.

J. Lawler

505 5th Avenue

New York, NY 10017

Radian Corporation

F. B. Mesich

P.0. Box 9948

Austin, TX 78766

Research Cottrel1

G. E. Collins

Hamon Cooling Tower Division

Box 750

Bound Brook, NJ 08805

Research Cottrell

R. H. Hannon

Hamon Cooling Tower Division

Box 750

Bound Brook, NJ 08805

Resources Conservation Company

H. Herrige 1

P.0. Box 936

Renton, WA 98055

Resources for the Future

D. Abbey

1755 Massachusetts Avenue NW Washington, DC 20036
No. of

Copies

Reynolds Aluminum Co.

R. Lindberg

Reynolds Metallurgical

Research Laboratory

Richmond, VA 23261

Richmond Field Station

H. H. Sephton

47th and Hoffman Blvd.

Richmond, CA 94804

San Diego Gas \& Electric

R. G. Lacy

101 Ash Street

San Diego, CA 92107

Seattle City Light

T. R. Miller

Principal Mechanical Engineer

1015 Third Avenue

Seattle, WA 98104

Seattle City Light

R. G. Sheehan

1015 Third Avenue

Seattle, WA 98104

Southern California Edison

R. S. Currie

2244 Walnut Grove Avenue

Rosemead, CA 91770

Southern California Edison

W. C. Martin

2244 Walnut Grove Avenue

Rosemead, CA 91770

Southern California Edison

F. A. McCracken

2244 Walnut Grove Avenue

Rosemead, CA 91770

Southern Services, Inc.

C. H. Goodman

P.0. Box 2625

Birmingham, AL 35202 
No. of

Copies

P. Sporn

Consultant Engineer

74 Trinity P1., Suite 511

New York, NY 10006

Stanford University

A. L. London

Department of Mechanical

Engineering

Stanford, CA 94305

Stearns-Rogers, Inc.

J. Y. Parce

Box 5888

Denver, CO 80217

Stewart-Warner Corporation

South Wind Division

V. N. Tramontini

1514 Dover Street

Indianapolis, IN 46221

Stone \& Webster Engineering Corp.

D. H. Guild

225 Frankl in Street

Boston, MA 02107

Tampa Electric Co.

H. I. Wilson

P.0. Box 111

Tampa, FL 33601

Tennessee Valley Authority

Energy Research

R. D. Boroughs

1345 Commerce Union Bank Building

Chattanooga, TN 37401

Tennessee Valley Authority

H. B. Flora, III

1320 Commerce Union Bank Bldg.

Chattanooga, TN 37401

Texas Electric Service Co.

W. Keel

$115 \mathrm{~W}$. Seventh Street

Fort Worth, TX 76102
No. of

Copies

Tucson Gas \& Electric

A. A. Ward

220 W. 6th Street

Tucson, AZ 85701

Union Carbide Corp.

J. A. Bartz

Linde Division

61 East Park Drive

Tonawanda, NY 14150

Union Carbide Corp.

G. J. Kidd

ORGDP - K-25

P.0. Box P, Mail Stop 197

Oak Ridge, TN 37803

Union Carbide Corp.

$F$. Notaro

Linde Division

61 East Park Drive

Tonawanda, NY 14150

United Engineers \& Constructors

G. A. Englesson

30 S. 17th Street

Philadelphia, PA 19103

United Engineers \& Constructors

M. $\mathrm{Hu}$

$30 \mathrm{~S} .17$ th Street

Philadelphia, PA 19103

University of Bremen

K. Simhan

Bremen, WEST GERMANY

University of Iowa

J. F. Kennedy

Hydraulic Research Institute

Iowa City, IA 52240

University of Kentucky

T. E. Eaton

Mechanical Engineering

Department

Lexington, KY 40506 
No. of

Copies

U.S. Congress

G. Haimes

214 Massachusetts Avenue NE Washington, DC 20510

U.S. Fish and Wildlife

Service

B. L. Foder

Information Transfer

Specialist

National Power Plant Team

1451 Green Road

Ann Arbor, MI 48105

United States Steel Corp.

T. L. Myron

Research Laboratory

Monroeville, PA 15146

Utah Power \& Light

M. W. Russon

1407 W. N. Temple

Salt Lake City, UT 84103

Vermont Yankee Nuclear Power

E. Gaines, Jr.

77 Grove Street

Rut1and, VT 05701

Virginia Electric \& Power Co.

$S$. Ragone

700 E. Franklin Street

Richmond, VA 23261

Washington Public Power

Supply System

J. Chasse

P.0. Box 968

300 George Washington Way

Richland, WA 99352

Washington State University

R. W. Crain, Jr.

Department of Mechanical

Engineering

Pullman, WA 99164
No. of

Copies

Washington Water Power Co.

D. L. 01son

E. 1411 Mission Avenue

Spokane, WA 99202

Water Purification Associates

H. Gold

238 Main Street

Cambridge, MA 02142

Western States Water Council

J. A. Barnett

Executive Director

220 South 2nd East

Suite 200

Salt Lake City, UT 84111

Westinghouse Electric Corp.

G. E. Jablonka

Power Generation Systems

Engineering

700 Braddock Avenue, Room 9L51

East Pittsburgh, PA 15112

Westinghouse Electric Corp.

K. Kesavan

Advanced Reactor Division

P.0. Box 158

Madison, PA 15663

Westinghouse Electric Corp.

G. J. Silvestri

Steam Turbines Division - G108

Lester Branch

Box 9175

Philadelphia, PA 19113

Westinghouse Electric Corp.

K. A. Oleson

Steam Turbines Division - G108

Lester Branch

Box 9175

Philadelphia, PA 19113

L. E. Wilkinson

Consultant

6582 Ganon Street, S.E.

Salem, OR 97301 
No. of

Copies

William M. Rice University

W. G. Characklis

Environmental Science and

Engineering

Houston, TX 77001

ONSITE

DOE Richland Operations Office

Energy Programs Division

H. E. Ransom

Westinghouse Hanford Company

Hanford Engineering Develop-

ment Laboratory

\section{J. Fletcher}

Pacific Northwest Laboratory

R. T. Allemann

J. A. Bamberger

Daniel J. Braun

David J. Braun

J. W. Currie

D. E. Deonigi

R. L. Dillon

D. W. Dragnich

R. L. Drake

F. P. Fabro

D. W. Faletti

J. W. Finnigan

J. D. Goodenough

J. J. Hauth

A. J. Haverfield

C. H. Henager

P. L. Hendrickson (10)

A. B. Johnson

W. S. Kelly

R. S. Kemper

W. V. Loscutoff

R. P. Marshal1

D. E. Olesen
No. of

Copies

Pacific Northwest Laboratory (contd)

Y. Onishi

H. L. Parry

L. T. Pederson

J. R. Sheff

G. C. Smith

J. S. Stoakes

A. M. Sutey

R. D. Tokarz

D. S. Trent

M. Vagins

R. A. Walter

R. L. Watts

R. D. Widrig

L. E. Wiles

C. E. Willingham

F. R. Zaloudek

File - B. M. Johnson (30)

Technical Information (5)

Publishing Coordination (2) 


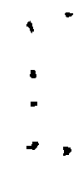

-

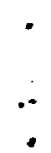

